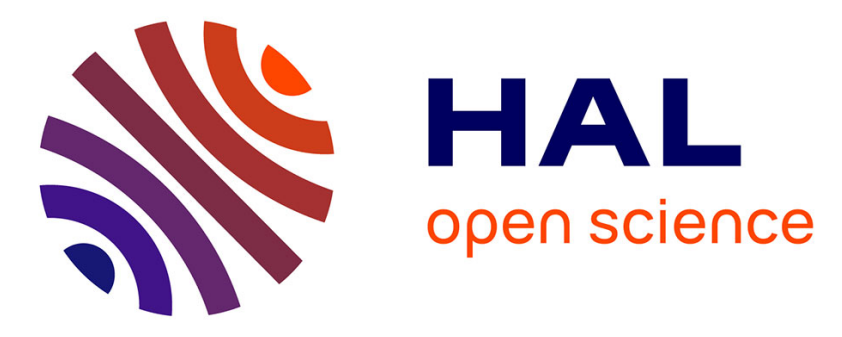

\title{
Strain localization in a fossilized subduction channel: Insights from the Cycladic Blueschist Unit (Syros, Greece)
}

Valentin Laurent, Laurent Jolivet, Vincent Roche, Romain Augier, Stéphane Scaillet, Giovanni Luca Cardello

\section{To cite this version:}

Valentin Laurent, Laurent Jolivet, Vincent Roche, Romain Augier, Stéphane Scaillet, et al.. Strain localization in a fossilized subduction channel: Insights from the Cycladic Blueschist Unit (Syros, Greece). Tectonophysics, 2016, 672-673, pp.150-169. 10.1016/j.tecto.2016.01.036 . insu-01290748

\section{HAL Id: insu-01290748 \\ https://hal-insu.archives-ouvertes.fr/insu-01290748}

Submitted on 18 Mar 2016

HAL is a multi-disciplinary open access archive for the deposit and dissemination of scientific research documents, whether they are published or not. The documents may come from teaching and research institutions in France or abroad, or from public or private research centers.
L'archive ouverte pluridisciplinaire HAL, est destinée au dépôt et à la diffusion de documents scientifiques de niveau recherche, publiés ou non, émanant des établissements d'enseignement et de recherche français ou étrangers, des laboratoires publics ou privés.

\section{(ㅇ)(1) $\$$}

Distributed under a Creative Commons Attribution - NonCommercial - NoDerivatives 44.0 
1 Strain localization in a fossilized subduction channel: insights from

2 the Cycladic Blueschist Unit (Syros, Greece)

3

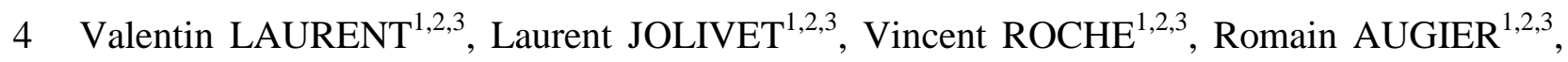

5 Stéphane SCAILLET ${ }^{1,2,3}$, Giovanni Luca CARDELLO ${ }^{1,2,3}$

6

$7 \quad{ }^{1}$ Université d'Orléans, ISTO, UMR 7327, 45071, Orléans, France

$8 \quad{ }^{2} \mathrm{CNRS} / \mathrm{INSU}$, ISTO, UMR 7327, 45071 Orléans, France

$9 \quad{ }^{3}$ BRGM, ISTO, UMR 7327, BP 36009, 45060 Orléans, France

10 valentin.laurent@univ-orleans.fr (corresponding author), laurent.jolivet@univ-orleans.fr,

11 v.roche@ brgm.fr, romain.augier@univ-orleans.fr, sscaille@cnrs-orleans.fr, luca.cardello@univ-

12 orleans.fr

13

14 Abstract:

Syros Island is worldwide known for its preservation of HP-LT parageneses in the

17 Cycladic Blueschist Unit (CBU) providing one of the best case-studies to understand the

18 tectonometamorphic evolution of a subduction channel. Conflicting structural interpretations

19 have been proposed to explain the geological architecture of Syros, in part reflecting a lack of

20 consensus about the tectonic structure of the CBU. In this study, the geological and

21 tectonometamorphic maps of Syros have been entirely redrawn in order to decipher the

22 structure of a fossilized subduction channel. Based on structural and petrological observations,

23 the CBU has been subdivided into three subunits separated by major ductile shear zones. New

24 observations of the Vari Unit confirm that it rests on top of the CBU through a detachment or

25 exhumation fault. While retrograde top-to-the E/NE shearing overprinting prograde 
26 deformation is widespread across the island, the prograde deformation has been only locally

27 preserved within the less retrograded units. We show that after the prograde top-to-the S/SW

28 shearing deformation, the CBU was exhumed by an overall top-to-the E/NE shearing from the

29 depth of the eclogite-facies all the way to the depth of the greenschist-facies and finally, to the

30 brittle crust. The exhumation process encompassed the syn-orogenic stage (contemporaneous

31 of subduction, within the subduction channel - Eocene) to the post-orogenic stage

32 (contemporaneous with the formation of the Aegean Sea - Oligocene to Miocene). From syn-

33 orogenic to post-orogenic exhumation, deformation progressively localized toward the base of

34 the CBU, along large-scale ductile shear zones, allowing the preservation of earlier HP-LT

35 structures and HP-LT metamorphic parageneses. Finally, this study brings new insights on the

36 tectonometamorphic evolution of a subduction channel showing how strain localizes during

37 the history of an accretionary complex, both during the prograde and retrograde history.

39 Keywords

40 Subduction channel; High-pressure low-temperature metamorphism; Strain localization;

41 Ductile shear zone; Cycladic Blueschist Unit; Syros Island

43 Highlights

44 1) New geological and tectonometamorphic maps of Syros (Cyclades, Greece)

45 2) The Cycladic Blueschist Unit (CBU) was exhumed by an overall top-to-the east shearing

46 3) The CBU was exhumed as separate subunits with distinct P-T evolutions

47 4) Exhumation process encompassed syn- to post-orogenic stage

48 5) During exhumation, strain localized downward along major extensional shear zones 
High-pressure low-temperature (HP-LT) metamorphic rocks are generally attributed to

54 former subduction zones. Intense retrograde deformation often overprints the early prograde

55 events, but in some key-areas, the prograde and metamorphic peak deformation can provide

56 insights on the tectonometamorphic history of a subduction zone (Alpine Corsica: Brunet et

57 al., 2000; Vitale-Brovarone et al., 2011; Norwegian Caledonides: Austrheim and Griffin,

58 1985; Andersen et al., 1994; Labrousse et al., 2004; Terry and Heidelbach, 2006; Raimbourg

59 et al., 2005; Himalaya: Burg et al., 1983; Liou et al., 2004; Epard and Steck, 2008; New

60 Caledonia: Bell and Brothers, 1985; Aegean domain: Keiter et al., 2004, 2011; Philippon et al.,

61 2011).

The Aegean domain and specifically the Cyclades Archipelago, form a natural

63 laboratory for studying a former subduction zone. Syros Island, located in the central part of

64 the Cyclades (Fig. 1a), is worldwide known for its spectacular preservation of deformed HP-

65 LT metamorphic rocks such as eclogites and is considered to be the type locality of

66 glaucophane (Hausmann, 1845). Rocks of this island have been the focus of many

67 petrological, geochronological and structural studies, leading to different interpretations

68 regarding: 1) the overall geometry of the $\mathrm{CBU}, 2)$ metamorphic peak conditions and 3) the

69 role of major tectonic contacts (Fig. 1b; Trotet et al., 2001a, 2001b; Rosenbaum et al., 2002;

70 Ring et al., 2003; Keiter et al., 2004, 2011; Schumacher et al., 2008; Philippon et al., 2011;

71 Soukis and Stöckli, 2013). Despite excellent outcropping conditions, these differences are

72 sometimes drastic, thus hindering our understanding of this classical example of a fossilized

73 subduction channel.

74 This paper focuses on the tectonometamorphic evolution of the Cycladic Blueschist

75 Unit. New maps and profiles are here further discussed in terms of their situation within the 
subduction channel. We demonstrate a progressive top-to-the E/NE continuum of deformation

77 from eclogite- to greenschist-facies. Most of the deformation completely overprinted the

prograde subduction-related deformation. However, we highlight areas where syn-burial

Detachment recently challenged by Philippon et al. (2011) as an extensional detachment
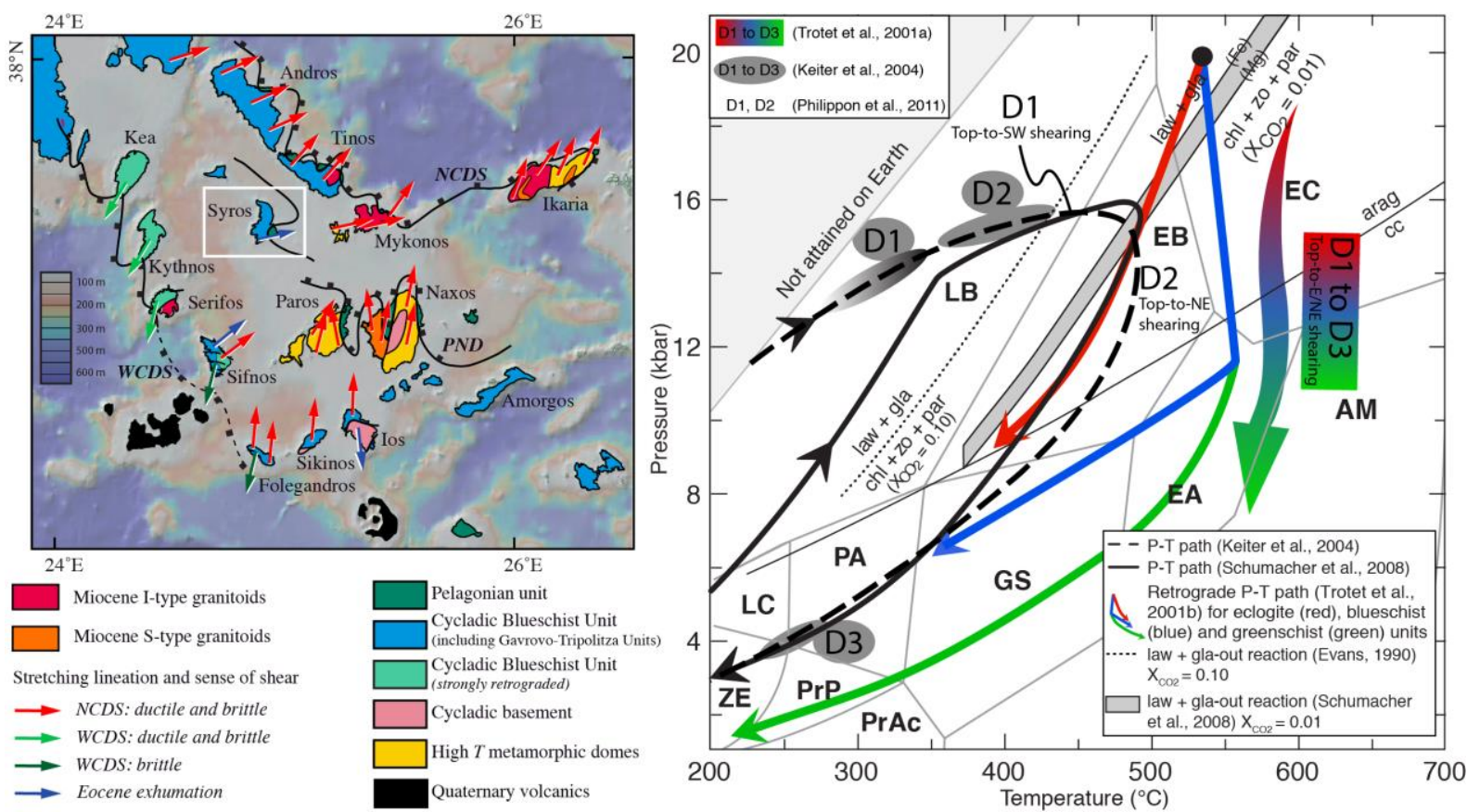

Figure 1: Localization of the studied area and Pressure-Temperature-deformation paths of Syros available in literature. a) Tectonic map of the Cyclades showing the major tectonic structures such as the North Cycladic Detachment System (NCDS), the West Cycladic Detachment System (WCDS) and the Paros-Naxos Detachment (PND), as well as kinematic indicators, after Jolivet et al. (2015). b) Representation of the different calculated PT paths for the CBU in Syros. D1, D2 and D3 phases of deformation after Trotet et al. (2001a, 2001b), Keiter et al. (2004), Philippon et al. (2011) highlight the conflicting prograde or retrograde interpretations of the main deformation observed on Syros. Facies: AM, amphibolite; EA, epidote-amphibolite; EB, epidote-blueschist; EC, eclogite; GS, greenschist; LB, lawsonite-blueschist; LC, lawsonite-chlorite; PA, pumpellyite-actinolite; PrAc, prehnite-actinolite; PrP, prehnite-pumpellyite; ZE, zeolite (after Peacock, 1993). Lawsonite + glaucophane-out reactions after Evans (1990) and Schümacher et al. (2008). 
2.1) Tectonometamorphic evolution of the Cycladic Blueschist Unit

The Aegean domain, part of the eastern Mediterranean Sea, experienced a two steps 104 tectonometamorphic evolution. Firstly, the late Cretaceous-Eocene formation of the 105 Hellenides-Taurides chain resulted from the subduction and collision of the Apulian 106 microcontinent with Eurasia (Bonneau and Kienast, 1982; Dercourt et al., 1986; van 107 Hinsbergen et al., 2005). The entrance of the Apulian crust in the subduction zone led to an episode of crustal thickening and syn-orogenic exhumation of HP-LT metamorphic units such

109 as the Cycladic Blueschist Unit (CBU; Fig. 1a; Blake et al., 1981; Bonneau and Kienast, 1982;

110 Jolivet et al., 2003, 2004; Brun and Faccenna, 2008; Jolivet and Brun, 2010; Ring et al., 2010).

111 Secondly, post-orogenic extension in the Rhodope from $45 \mathrm{Ma}$ and in the Aegean Sea from $11235 \mathrm{Ma}$ was associated with the retreat of the African slab (Jolivet and Faccenna, 2000; Brun 113 and Sokoutis, 2010; Jolivet and Brun, 2010; Ring et al., 2010). In the Aegean domain, part of

114 western Anatolia and in the Rhodope Massif, back-arc extension of the previously thickened 115 crust was accommodated by several regional-scale detachments such as the North Cycladic 116 Detachment System (NCDS) or the West Cycladic Detachment System (WCDS) (Fig. 1a; 117 Jolivet et al., 2010; Grasemann et al., 2012).

118 Located in the center of the Aegean domain, the Cyclades correspond to the deepest 119 exhumed parts of the Hellenides-Taurides chain and are mainly composed by the CBU (Fig. 120 1a). This unit is mainly made of marbles, metapelites and metabasites all showing peak P-T 121 conditions in the blueschist- or eclogite-facies (Blake et al., 1981; Bonneau, 1984; Okrush and 122 Bröcker, 1990; Avigad and Garfunkel, 1991; Trotet et al., 2001b; Schumacher et al., 2008).

123 The CBU experienced alpine tectonic and metamorphic evolution, with an early burial in HP- 
124 LT conditions reaching $\sim 18-20 \mathrm{kbar}$ and 500-550 ${ }^{\circ} \mathrm{C}$ (Fig. 1b; Dürr et al., 1978; Bröcker and

125 Enders, 2001; Trotet et al., 2001b; Parra et al., 2002; Tomaschek et al., 2003; Augier et al.,

126 2015) during the Eocene ( 50-35 Ma; Tomaschek et al., 2003; Putlitz et al., 2005; Lagos et al.,

127 2007). During the Oligocene and for the whole Miocene, this event was followed by LP-HT

128 greenschist- to amphibolite-facies overprint of variable intensity (Fig. 1a; Altherr et al., 1979,

129 1982; Wijbrans and McDougall, 1986; Buick, 1991; Keay et al., 2001; Vanderhaeghe, 2004;

130 Duchêne et al., 2006; Bröcker et al., 2013; Beaudoin et al., 2015). On top of the CBU, the

131 Upper Cycladic Unit (UCU) corresponds to the uppermost parts of the nappe stack. The UCU

132 is composed of Permian to Mesozoic metasediments, minor orthogneisses and ophiolites

133 equilibrated in greenschist- to amphibolite-facies metamorphic conditions during the

134 Cretaceous, sometimes covered with Oligocene to Miocene sediments (Sanchez-Gomez et al.,

135 2002; Kuhlemann et al., 2004; Lecomte et al., 2010; Menant et al., 2013). Structurally below

136 the CBU, the Cycladic Continental Basement (CCB) crops out as large-scale tectonic

137 windows on several islands in the central and southern part of the Cyclades (Fig. 1a; e.g.

138 Paros, Naxos, Ios or Sikinos; Andriessen et al., 1987). This unit is composed of Variscan

139 orthogneisses enveloped by metasediments that locally retain metamorphic relics of

140 amphibolite-facies assemblages suggesting a complex pre-alpine history (Bonneau and

141 Kienast, 1982; Andriessen et al., 1987; Keay, 1998; Photiades and Keay, 2003; Gupta and

142 Bickle, 2004; Huet et al., 2009; Augier et al., 2015). Late exhumation stages of both the CBU

143 and the CCB were accompanied by emplacement of syn-tectonic Miocene intrusions (i.e.

144 Tinos, Mykonos, Ikaria, Naxos, Serifos, Lavrio; Fig. 1a; Jansen, 1973; Altherr et al., 1982;

145 Faure et al., 1991; Lee and Lister, 1992; Altherr and Siebel, 2002; Pe-Piper et al., 2002;

146 Grasemann and Petrakakis, 2007; Iglseder et al., 2009; Bolhar et al., 2010; Lecomte et al.,

147 2010; Stouraiti et al., 2010; Denèle et al., 2011; Laurent et al., 2015; Rabillard et al., 2015). 
Located in the central part of the Aegean domain, Syros is mainly composed by the

152 CBU except for the Vari Unit (Fig. 2a). Vari Unit, composed of greenschist mylonites and

153 orthogneiss, corresponds to a distinct tectonic unit attributed to UCU, separated from the CBU

154 by the Vari Detachment (Trotet et al., 2001a; Keiter et al., 2004, 2011; Soukis and Stöckli,

155 2013). The basal part of the CBU crops out in the southwestern part of the island and is 156 mainly composed of albitic micaschists and rare gneisses (e.g. the Komito gneiss; Fig. 2a;

157 Hecht, 1985). Structurally above, the central part of Syros is dominated by alternating 158 sequences of marble and micaschist layers (Fig. 2a). In this area, metabasites are a minor 159 component and often occur as dismembered boudins intercalated within the metamorphic 160 series. Conversely, in other parts of the island and especially in the north, metabasites form 161 the dominant lithology and often occur as kilometer-scale massive bodies (e.g. Hecht, 1985; 162 Keiter et al., 2004, 2011; Philippon et al., 2011). Metabasites are locally turned into massive 163 eclogite-facies rocks but also occur as blueschist- or greenschist-facies rocks (Trotet et al., 164 2001a).

2.3) Pressure-Temperature-time evolution

Petrological studies yielded contrasting estimates for metamorphic peak conditions 169 from 15-16 kbar and 500 ${ }^{\circ} \mathrm{C}$ (Schliestedt et al., 1987; Okrusch and Bröcker, 1990; Avigad and 170 Garfunkel, 1991; Schmädicke and Will, 2003; Schumacher et al., 2008) to 19-20 kbar and $171525-550^{\circ} \mathrm{C}$ (Fig. 1b; Trotet et al., 2001b; Groppo et al., 2009; Dragovic et al., 2012; Ashley et 172 al., 2014). Timing and duration of this subduction-related P-T evolution have been quite well 173 constrained since the 1980 s, using a large panel of isotopic systems such as $\mathrm{K}-\mathrm{Ar},{ }^{40} \mathrm{Ar} /{ }^{39} \mathrm{Ar}$, 
$174 \mathrm{Rb}-\mathrm{Sr}, \mathrm{U}-\mathrm{Pb}, \mathrm{Lu}-\mathrm{Hf}, \mathrm{Sm}-\mathrm{Nd}$ systems on various minerals (Fig. 2b; Altherr et al., 1979, 1982;
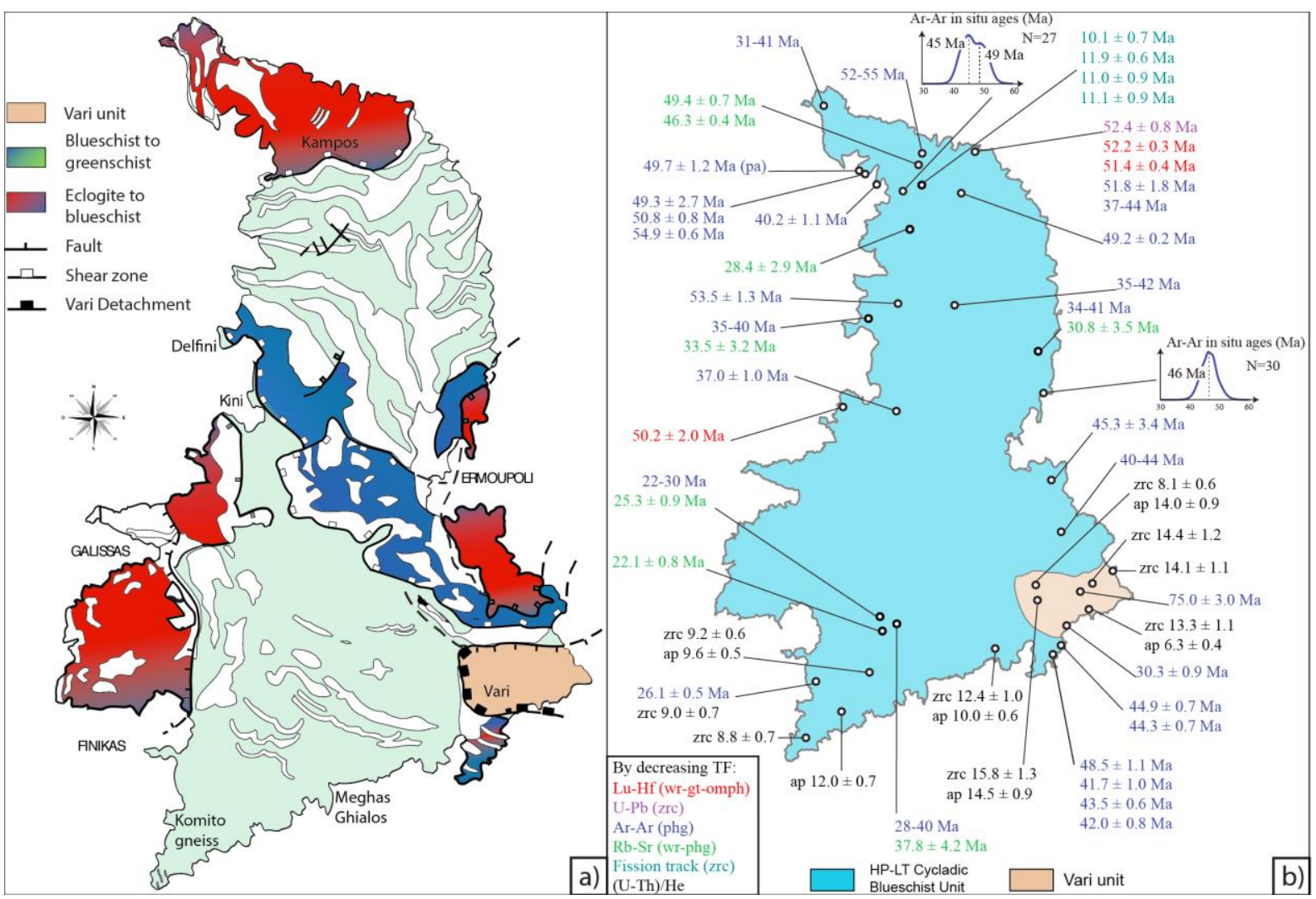

Figure 2: Previous geological and geochronological works on Syros. a) Metamorphic map of Syros showing the main tectonic structures, after Trotet et al. (2001a). b) Compilation of previous geochronological data calculated after U-Pb (Bröcker \& Enders, 1999; Tomaschek, et al., 2003), Lu-Hf (Lagos, et al., 2007), ${ }^{40} \mathrm{Ar} /{ }^{39} \mathrm{Ar}$ (Maluski et al., 1987; Tomaschek, et al., 2003; Putlitz et al., 2005; Huet, 2010; Bröcker et al., 2013), Rb-Sr (Bröcker \& 
The relative importance of the prograde and retrograde deformations, compression $v s$ extension, syn-orogenic vs post-orogenic exhumation is still debated. Hecht (1985) elaborated

197 the geological map of Syros at the scale 1: 50000 and interpreted all basal contacts of 198 metabasites as tectonic, mostly as thrusts, contradicting the initial interpretation of metabasite 199 occurences as olistoliths within a flysch sequence (Bonneau et al., 1980a, 1980b; Blake et al., 200 1981). Recently, Keiter et al. (2011) remapped the entire island at the scale 1: 25000. These 201 authors argued that an important result of their study is the identification of a significant late 202 brittle deformation on Syros that was so far poorly constrained. In parallel, Philippon et al. 203 (2011) reinterpreted the geological map of Syros, based on the original map of Hecht (1985). 204 These authors disconfirmed the existence of the Vari Detachment, correlating the Vari and 205 Komito gneisses and repositioning the Vari Unit at the base of the CBU. Soukis and Stöckli 206 (2013) challenged this conclusion, restoring the original interpretation of Gautier (1995), 207 Trotet et al. (2001a) or Ring et al. (2003), thus recognizing the juxtaposition of the Vari Unit 208 onto the CBU by the Vari Detachment. A second controversy relates to the regional and 209 tectonic significance of the deformation recorded by HP-LT rocks. According to Trotet et al. 210 (2001a), the main deformation phase is retrograde and was acquired during exhumation of the

211 CBU from eclogite- to greenschist-facies (D1 to D3; Fig. 1b). For these authors, exhumation 212 occurred during a continuum of top-to-the E/NE shearing deformation from the early Eocene 213 (syn-orogenic exhumation) to the early Miocene (post-orogenic exhumation). In contrast, 214 Keiter et al. $(2004,2011)$ interpreted the main deformation event affecting the CBU as 215 prograde, implying therefore a rigid body exhumation of the whole structure (D1 to D3; Fig. 216 1b). Finally, Philippon et al. (2011) describe two distinct ductile phases of deformation (Fig. 
217 1b), i) a first top-to-the SW prograde deformation (D1) and, ii) a second extensional top-to-

218 the NE penetrative shear (D2) affecting the entire CBU.

219 As long as these discrepancies are not addressed, the deep processes and long-term

220 evolution of the CBU in the subduction channel will remain poorly understood.

222 3) A new geological map of Syros

224 3.1) Method and mapping technique

In order to complement existing geological maps and put constraints on the geometry

227 of Syros, the whole island has been remapped based on field observations and satellite-images

228 interpretation (Fig. 3). Lithology and tectonic boundaries have been redrawn following our

229 observations all over the island. For mutual comparison, the color code of the legend is the

230 same as in the geological map of Keiter et al. (2011), with simplified lithologic subdivisions

231 for the purpose of our tectonometamorphic study. Calcitic and dolomitic marbles were

232 merged together into a unique metacarbonate comprehensive unit. Similarly, further

233 subdivisions within the mafic protoliths were abandoned. Anyway, principal occurrences of

234 serpentinite and eclogite are reported on the map (Fig. 3). Additionally, the finite strain

235 markers were studied as well as the link with the metamorphic record. Results are given on

236 figure 3. 


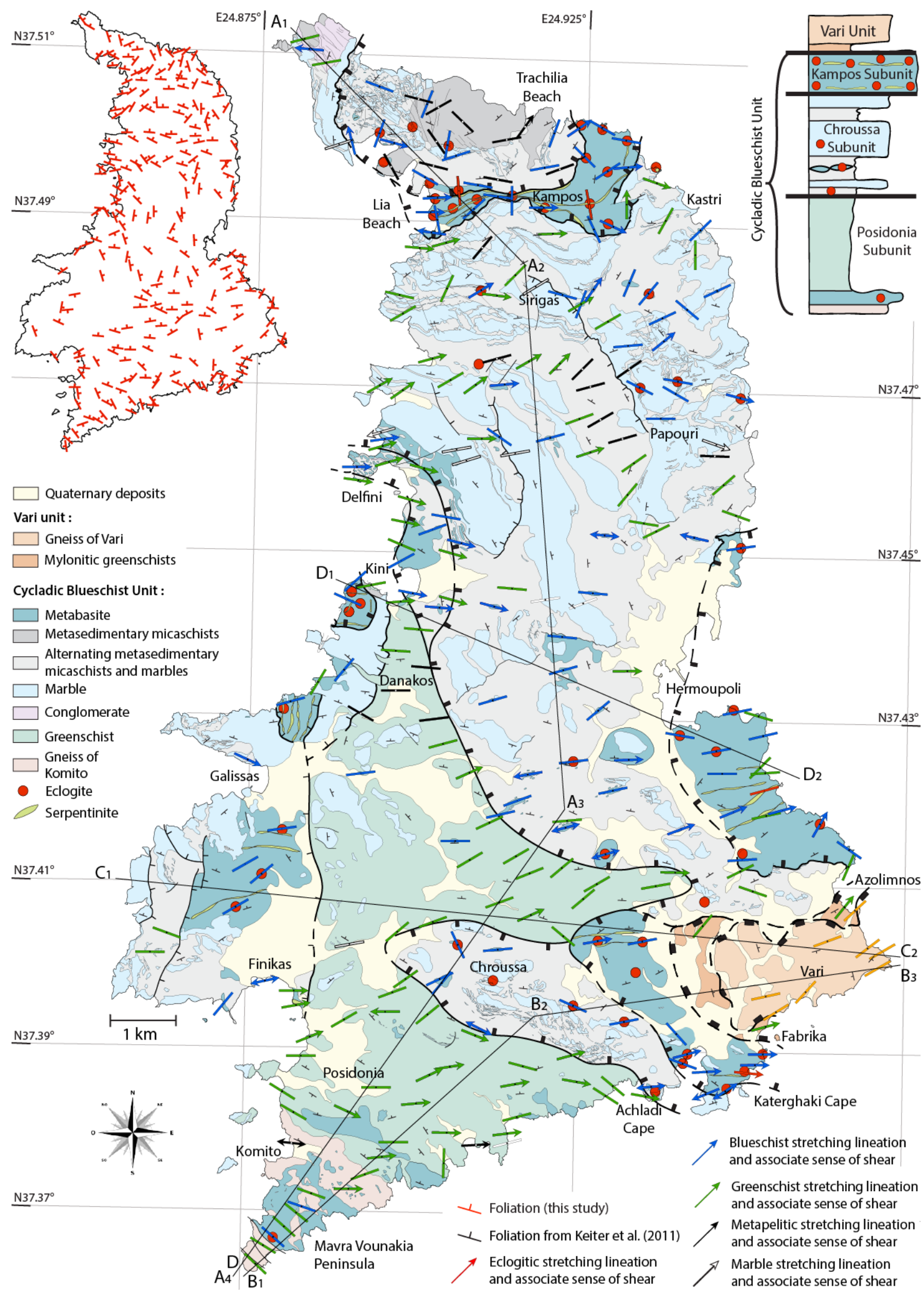

Figure 3: New geological map of Syros showing the main tectonic structures and lithologic distributions (geometry of the Vari Unit after Soukis and Stöckli, 2013). Cross-sections are traced with black lines and highlight the architecture of Syros. Planar (foliation planes) and linear (stretching lineations) fabrics are represented with their associated metamorphic facies. Also shown are the localities cited in the text. 


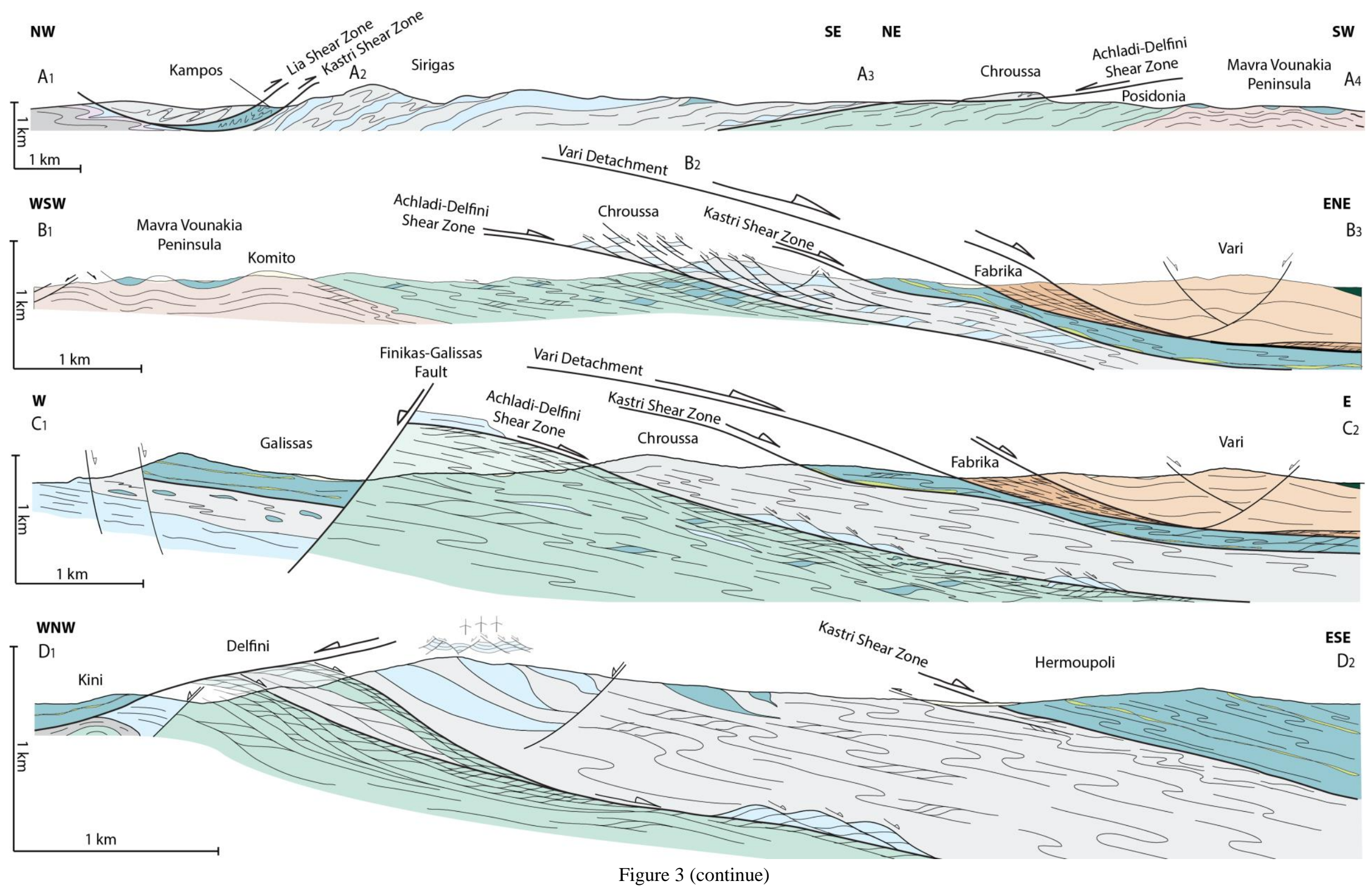


From a lithological point of view, our new geological map does not significantly differ

247 from the one of Keiter et al. (2011) with only few areas where minor changes are reported; the 248 map thus seems relatively robust. As examples of differences, we highlight larger outcrops of 249 metabasites in several parts of the island, like in Mavra Vounakia peninsula or near the 250 Delfini Bay (Fig. 3).

The most obvious changes are related to the structural aspects in a broad sense, and

252 particularly the way the metamorphic sequence is structured in coherent units. Our approach 253 consisted first in the identification of high strain zones (i.e. major shear zones) where 254 deformation is concentrated, and second, in the recognition of subunits characterized by their 255 lithological content and metamorphic record. This mapping approach allows us redefining the 256 stack of the CBU, subdividing it in three subunits delimited by major shear zones, which are 257 from bottom to top:

258 1) Posidonia Subunit, which is lithologically subdivided in two parts: the structurally lower 259 felsic gneiss of Komito with intercalated boudins of metabasite, overlain by albitic 260 micaschists, few metabasites and thin marble layers (Fig. 3). The entire basal unit has been 261 overprinted in the greenschist-facies with only few areas preserving high-pressure relics in 262 centimeter-scale mafic boudins (Fig. 3). The Achladi-Delfini Shear Zone delimits the 263 Posidonia Subunit from the upper Chroussa Subunit.

264 2) Chroussa Subunit, which is composed of a lithostratigraphic sequence of alternating 265 micaschists, thick marble layers and metabasites (Fig. 3). Although some areas are more 266 overprinted in the greenschist-facies, blueschist-facies parageneses are well preserved in this

267 subunit. Fresh eclogites are sometimes preserved in the core of metabasic boudins of any 268 scale (Fig. 3). The Kastri Shear Zone delimits the Chroussa Subunit from the upper Kampos 
Subunit.

270 3) Kampos Subunit, which is mainly composed of a mélange of metabasites, including 271 metagabbros, metabasalts, and locally still visible remains of metapillow-lavas (see Keiter et 272 al., 2011 for details) wrapped by strongly foliated metapelites and/or serpentinites. Within this 273 subunit, eclogite- and blueschist-facies parageneses are preserved, with only few narrow 274 zones overprinted in the greenschist-facies (Fig. 3). The Vari Detachment delimits the top of 275 Kampos Subunit, and at larger scale the entire CBU, from the upper Vari Unit.

276 Finally, the Vari Unit is formed from bottom to top by a greenschist mylonitic unit and

277 the gneiss of Vari intruding amphibolite-facies metabasites (see also Soukis and Stöckli, 278 2013). High-pressure rocks were not recognized in the Vari Unit.

4) Deformation and metamorphic record in the $\mathrm{CBU}$

Finite strain markers were studied throughout the island. In parallel, physical conditions

283 of the deformation were evaluated by the recognition of syn-kinematic minerals in 284 metabasites and other types of lithologies. All three subunits experienced HP-LT imprint in 285 the eclogite-facies conditions. This initial record is however unevenly distributed. In this 286 section we explore the relationships between the preservation/retrogression of HP-LT 287 parageneses and the relative intensity of deformation. 

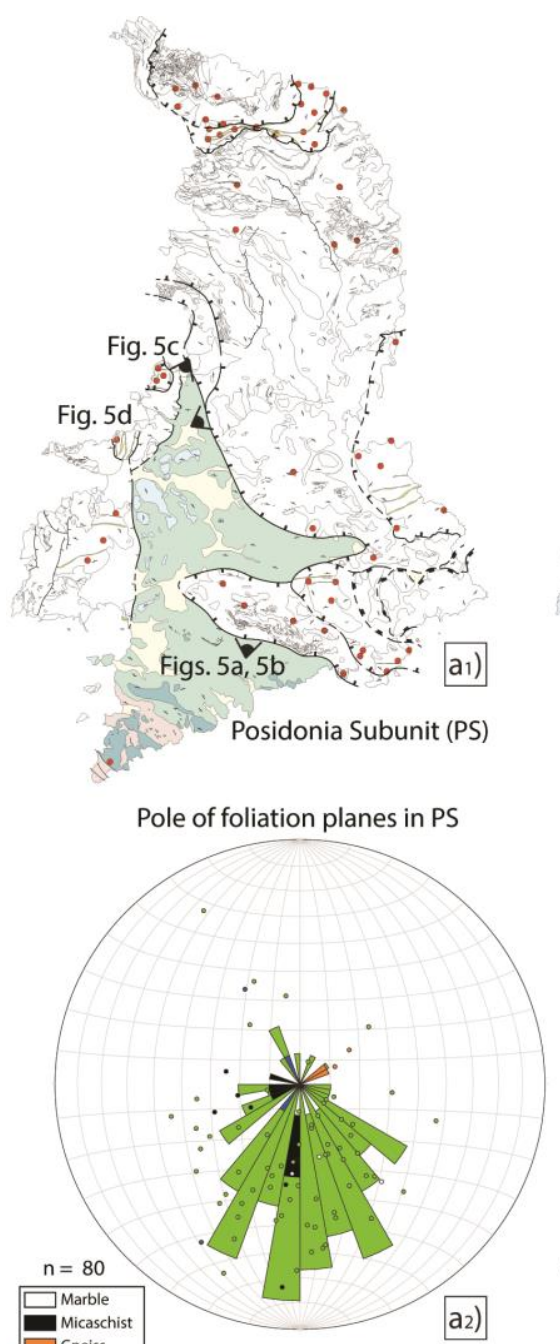
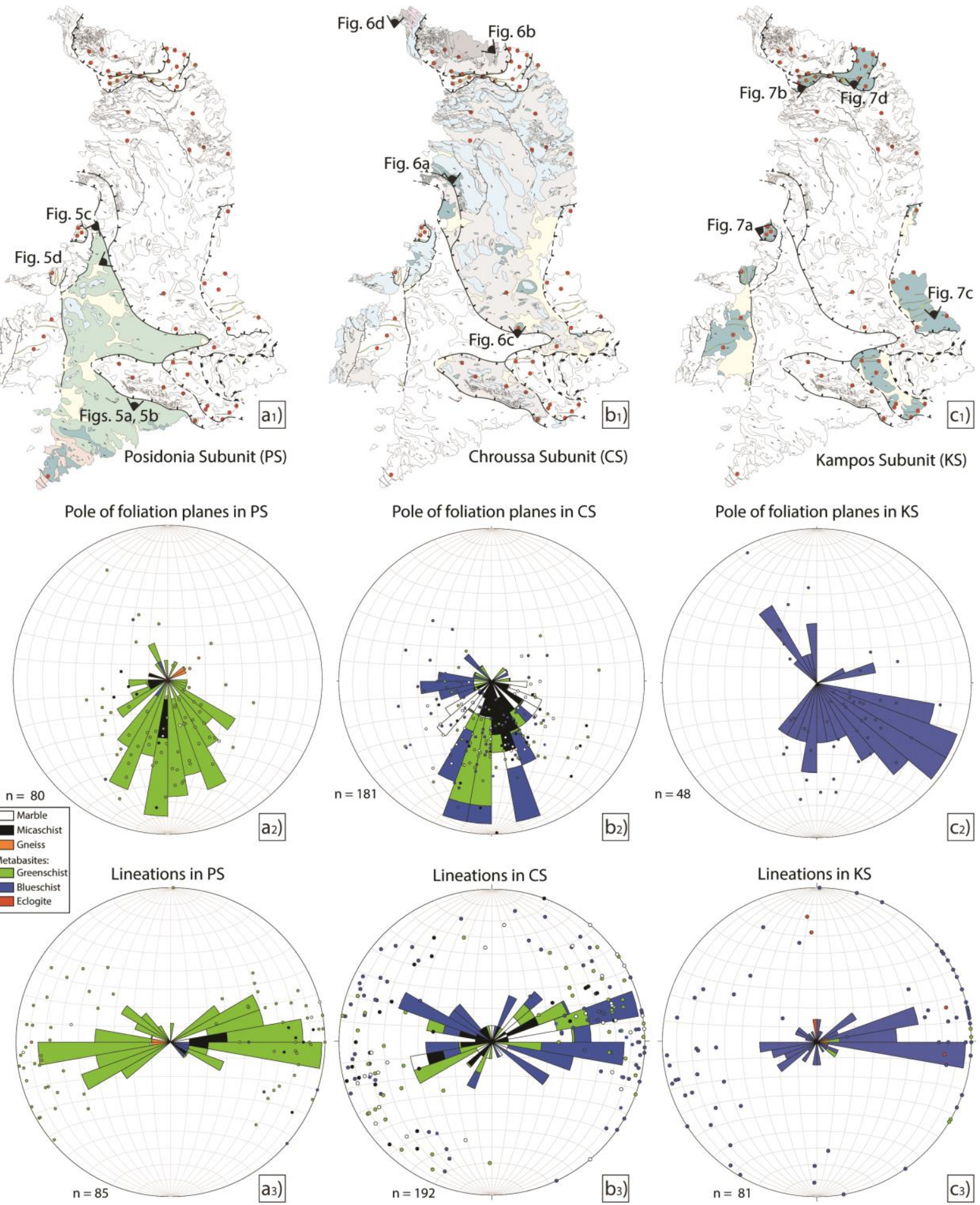

C2)
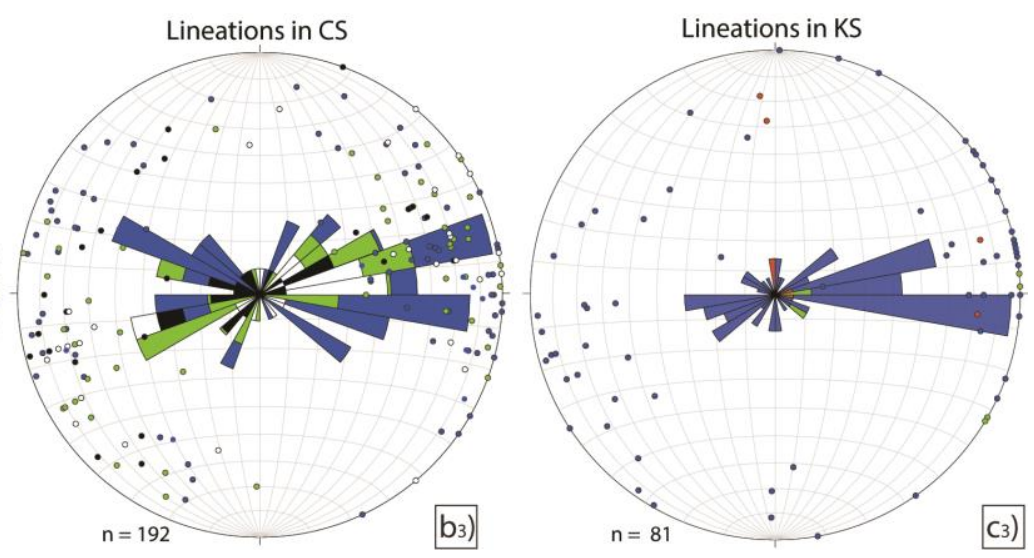

Figure 4: Stereograms of the planar and linear fabric measured on Syros and their associated metamorphic facies or lithology if mineralogy does not allow identifying the metamorphic-facies. $a_{1}, b_{1}, c_{1}$ ) Geological maps highlighting respectively the Posidonia, Chroussa and Kampos subunits and localizing the pictures displayed on the figures 5, 6 and 7. $a_{2}, b_{2}, c_{2}$ ) Rose diagram of the poles of foliation planes in each subunit. $a_{3}, b_{3}, c_{3}$ ) Rose diagram of stretching lineations in each subunit. 
Foliation in Posidonia Subunit dips shallowly toward NNW to NNE (Fig. 4a). A syn-

301 greenschist facies stretching lineation is observed almost systematically, marked by the 302 stretching of syn-kinematic chlorite and/or albite in rocks showing only greenschist 303 parageneses (Fig. 4a). Syn-blueschist lineations were observed in only four outcrops (Fig. 3). 304 For each of these areas, HP-LT markers are preserved within up to a few meters thick mafic 305 to ultra-mafic boudins hosted in greenschist-facies rocks. The trend of stretching lineations 306 varies between $\mathrm{N} 60^{\circ} \mathrm{E}$ to $\mathrm{N} 100^{\circ} \mathrm{E}$ with a dominant E-W orientation (Fig. 4a). Foliation planes 307 and stretching lineations measured in the Mavra Vounakia Peninsula (Fig. 3) are slightly 308 different from those observed in the rest of Posidonia Subunit. There, foliation planes 309 measured in gneiss and metabasites are NW-SE trending with oscillating dip direction toward 310 the NE or SW and carried stretching lineations oriented between $\mathrm{N} 120^{\circ} \mathrm{E}$ and $\mathrm{N} 140^{\circ} \mathrm{E}$ (Fig. 3 ). 311 In Posidonia Subunit, markers of non-coaxial ductile deformation are observed as 312 shear bands, sigma-clast systems, drag folds or asymmetric boudinage. For more than $90 \%$ of 313 visited outcrops, these markers indicate a consistent syn-greenschist top-to-the east sense of 314 shear (Figs. 3, 5a, 5b). Additionally, the rocks of Posidonia Subunit are tightly to isoclinally 315 folded, with fold axes either parallel or perpendicular to the stretching direction (Figs. 5c, 5d). 


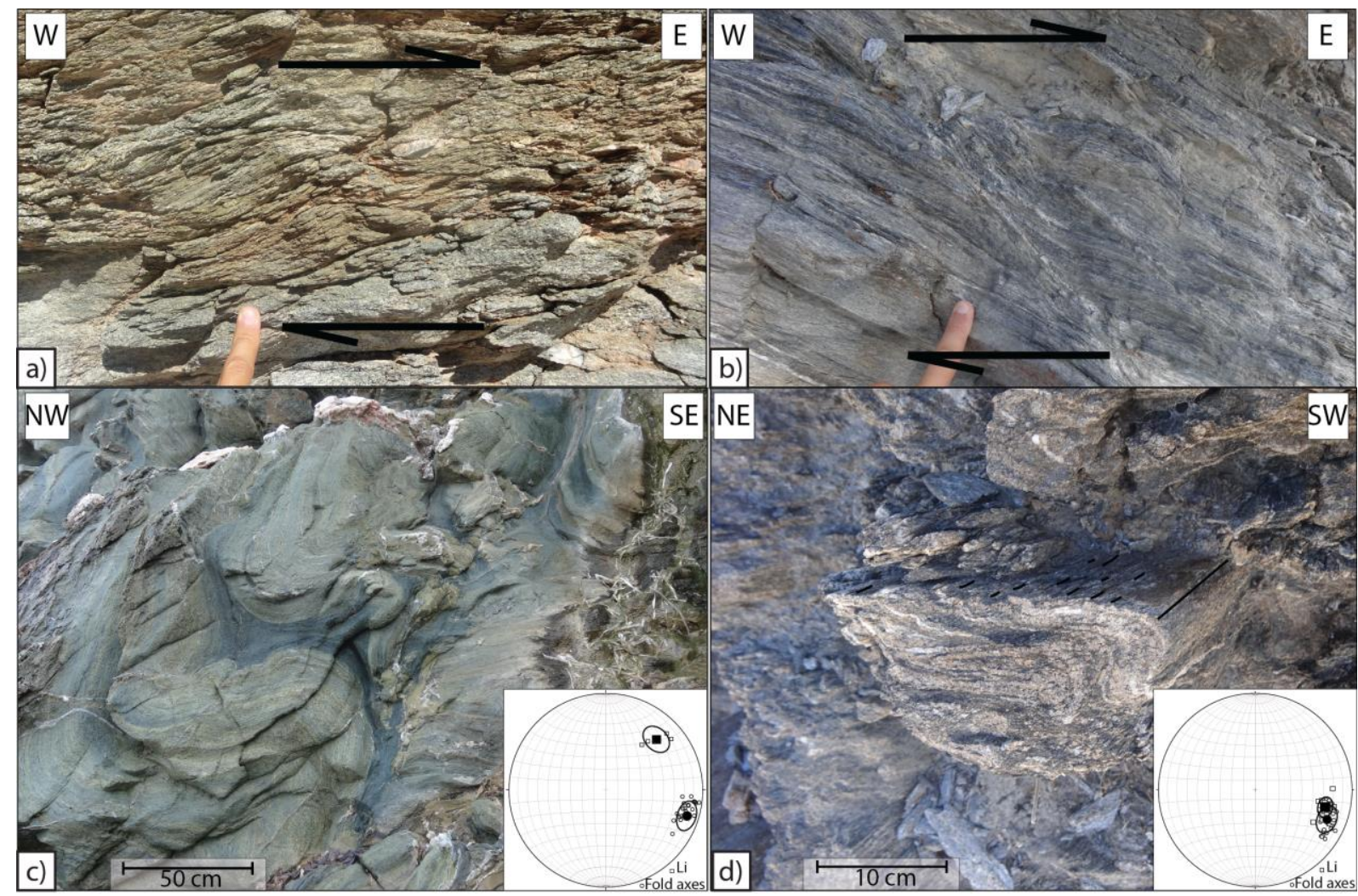

318 Figure 5: Syn-greenschist top-to-the east shearing characterizing the Posidonia Subunit. Localization of pictures 319 is showing on figure $4 \mathrm{a}_{1}$. a, b) Syn-greenschist top-to-the east shear bands (GPS coordinate: $37^{\circ} 23^{\prime} 16.2^{\prime \prime}$ / $\left.32024^{\circ} 54^{\prime} 21.5^{\prime \prime}\right)$ c) Greenschist folds characterized by orthogonal fold axes compared to syn-greenschist stretching 321 lineations (GPS coordinate: $37^{\circ} 26^{\prime} 40.5^{\prime \prime}$ / 24 $4^{\circ} 53^{\prime} 53.8^{\prime \prime}$ ). Data are plotted on the stereogram. d) Parallel fold 322 axes and syn-greenschist stretching lineations observed in the contact zone with the Chroussa Subunit near the

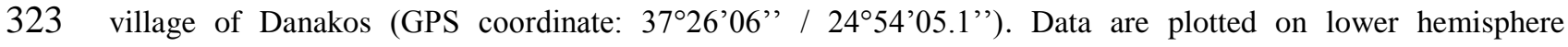
324 stereograms. metabasites, showing both syn-blueschist and syn-greenschist deformation (Fig. 4b).

330 Measured foliation planes shallowly dip to north (Fig. 4b) with local variations. Within 331 blueschist-facies rocks, a group of N-S striking foliation planes dips eastward (Fig. 4b). Two 332 other orientations of foliation planes were measured in marbles, dipping toward the NE or the 333 NW (Fig. 4b). As for Posidonia Subunit, only a few foliation planes dip southward. The 334 planar fabric observed in Chroussa Subunit is often associated with a stretching lineation 335 marked by glaucophanes needles in blueschist-facies rocks and chlorite and/or albite pods in 
336 greenschist-facies rocks (Fig. 4b). Overall, the bulk of measured stretching lineations shows a

337 constant orientation with a rather low dispersion between $\mathrm{N} 70^{\circ} \mathrm{E}$ and $\mathrm{N} 100^{\circ} \mathrm{E}$. A subordinate

$338 \mathrm{~N} 20^{\circ} \mathrm{E}$ set of lineations is observed in blueschist-facies rocks (Fig. 4b).

339 Rocks of Chroussa Subunit are strongly deformed at all scales. Markers of non-coaxial

340 ductile deformation are similar to those observed in Posidonia Subunit. Likewise, this subunit

341 shows top-to-the E/NE ductile deformation for both syn-blueschist and syn-greenschist

342 markers (Figs. 6a, 6b, 6c). In the northern part of Syros, near Trachilia Beach, top-to-the

343 northeast shear bands affecting lawsonite pseudomorphs in metapelites occur (Fig. 6b). In few

344 places, we observed in the Chroussa Subunit shear bands or asymmetric boudinage showing

345 retrograde top-to-the west deformation (Figs. 3, 6c). Folds are also common in Chroussa

346 Subunit showing curved axes locally parallel to the stretching lineation and axial closures like

347 in sheath folds (Fig. 6d). 

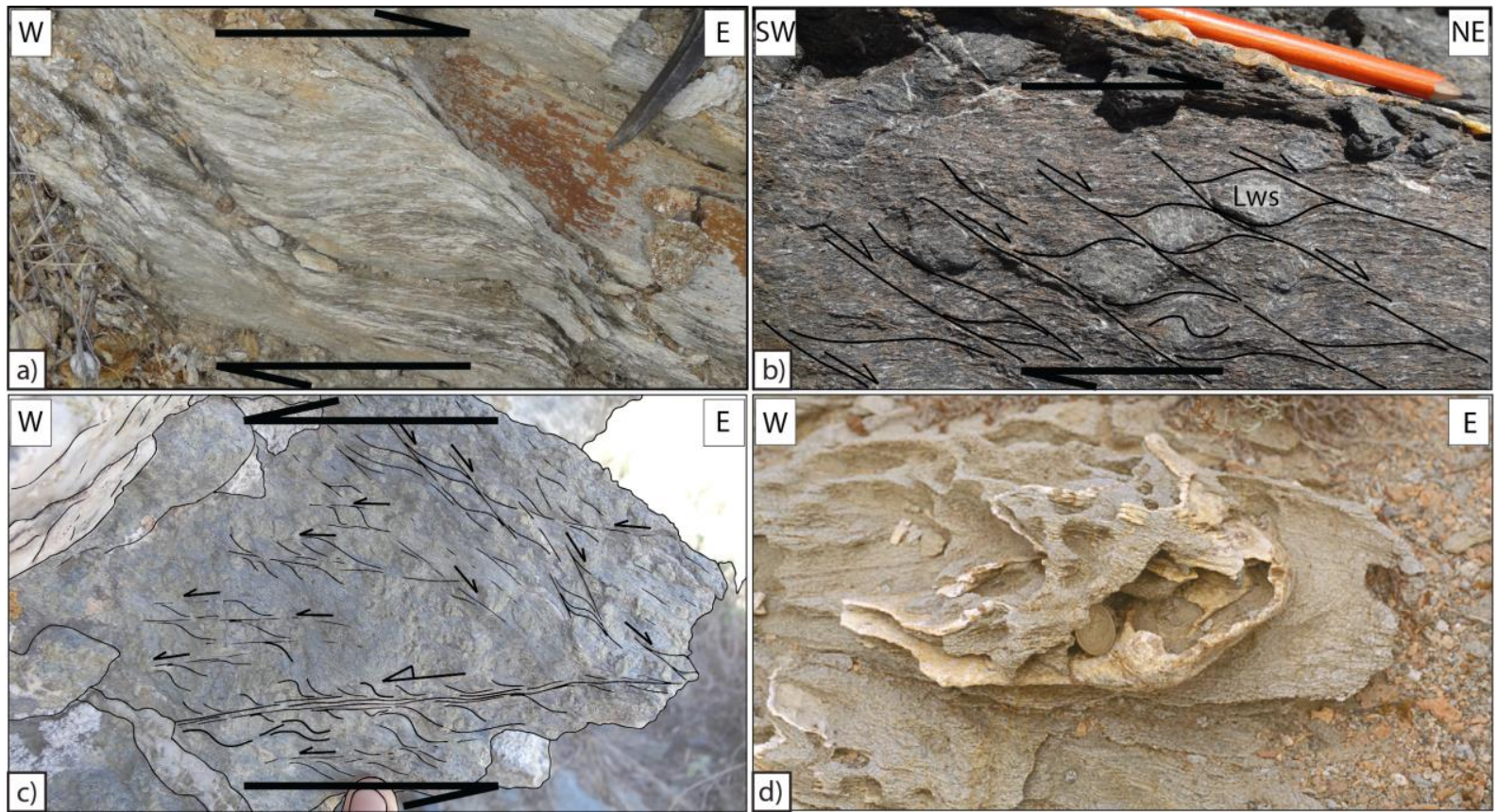

Figure 6: Shearing criteria observed in Chroussa Subunit. Outcrop location is shown on figure $4 \mathrm{a}_{2}$. a) Syngreenschist top-to-the east shear bands (GPS coordinate: $37^{\circ} 28^{\prime} 24.1^{\prime \prime} / 24^{\circ} 55^{\prime} 11.6^{\prime \prime}$ ). b) Top-to-the northeast shear bands affecting preserved pseudomorphs of lawsonite (GPS coordinate: $\left.37^{\circ} 30^{\prime} 07.9^{\prime \prime} / 24^{\circ} 54^{\prime} 54.4^{\prime \prime}\right)$. c) Retrograde top-to-the west shearing observed locally in the Chroussa Subunit (GPS coordinate: $37^{\circ} 24^{\prime} 49.3^{\prime \prime}$, / $\left.24^{\circ} 55^{\prime} 45.5^{\prime \prime}\right)$. The steep shear planes are secondary shear zones rotating top west with an antithetic sense of shear. d) Curved axis fold observed in micaschists, sub-parallel to the stretching lineation and showing closure

Kampos Subunit displays rocks equilibrated in eclogite- and blueschist-facies.

Foliation planes dip toward north or northwest (Fig. 4c). Stretching lineations are mainly oriented between $\mathrm{N} 70^{\circ} \mathrm{E}$ and $\mathrm{N} 100^{\circ} \mathrm{E}$ and dominantly marked by elongated glaucophane minerals along a main stretching direction (Fig. 4c). N-S syn-blueschist stretching lineations are common in the metabasites near Kampos village (Figs. 3, 4c). In some outcrops (e.g. Kini,

370 Kampos or near the airport), metabasite bodies show only incipient deformation with 371 preserved metapillow-lavas or metabasaltic dykes crosscutting metagabbros (Fig. 7a).

372 Conversely, in others outcrops, rocks experienced intense top-to-the-east shearing recorded

373 during retrogression of eclogites in blueschist-facies conditions (Fig. 7). This characteristic 

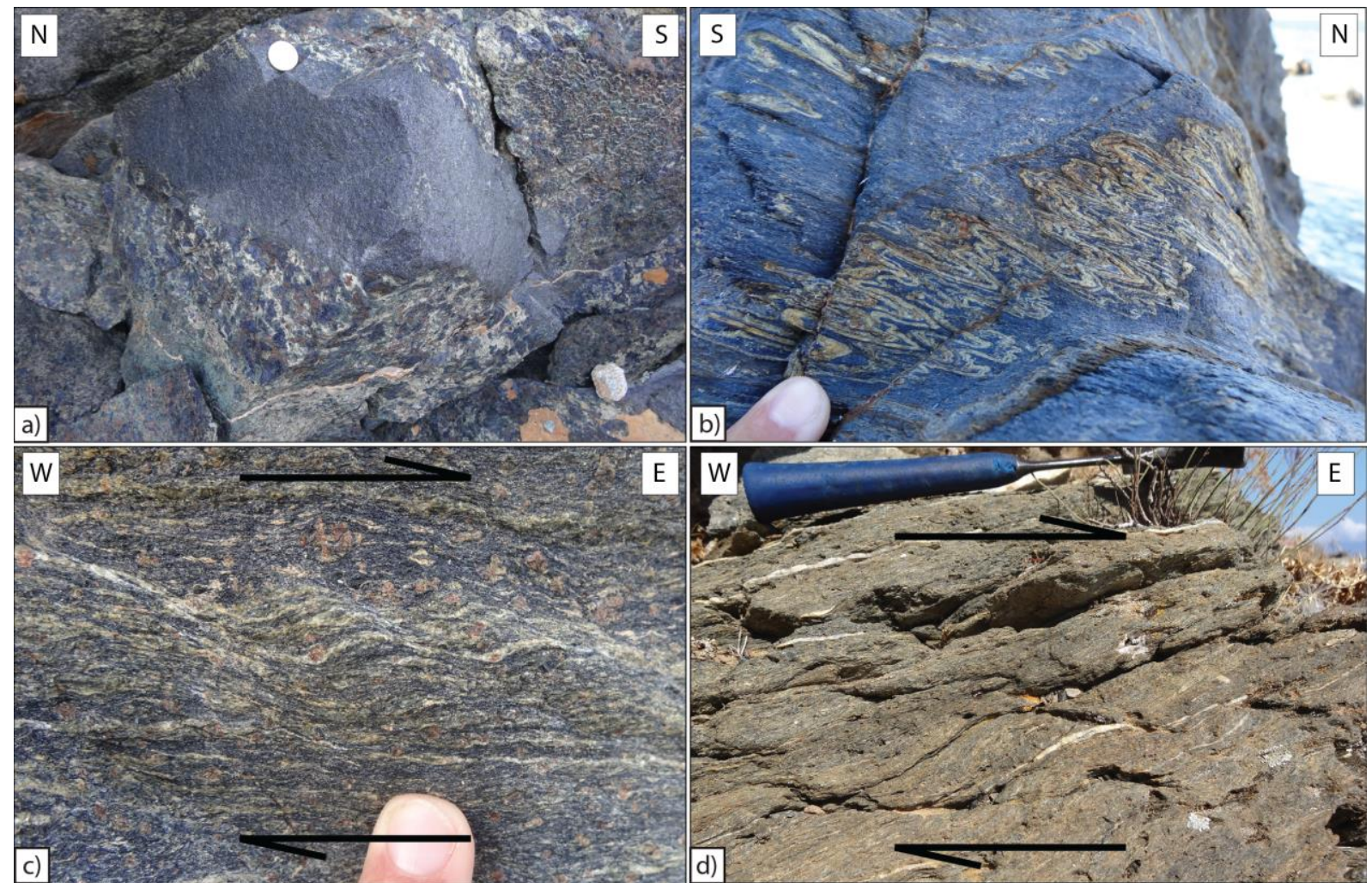

4.4) Brittle deformation

Ductile features are affected by late, sometime pervasive, brittle deformation recorded

Figure 7: Intense syn-eclogite to blueschist-facies deformation of Kampos Subunit illustrating top-to-the east sense of shear. Localization of pictures is showing on figure $4 \mathrm{a}_{3}$. a) Metabasaltic dyke cross-cutting a massive metagabbro unit showing no deformation (GPS coordinate: $37^{\circ} 26^{\prime} 43.6^{\prime \prime} / 24^{\circ} 53^{\prime} 20.4^{\prime \prime}$ ). b) Isoclinal folds characterized by sub-horizontal axes parallel to the stretching lineation. These folds show intense thinning during shearing with pure shear component during deformation (GPS coordinate: $\left.37^{\circ} 29^{\prime} 19.2^{\prime \prime} / 24^{\circ} 54^{\prime} 03.4^{\prime \prime}\right)$. c, d) Syn-blueschist top-to-the east shearing affecting high-pressure metabasites (GPS coordinate: c) $37^{\circ} 25^{\prime} 05.3^{\prime \prime}$ / $24^{\circ} 57^{\prime} 42.9^{\prime \prime}$ d) $\left.37^{\circ} 29^{\prime} 22.6^{\prime \prime} / 24^{\circ} 55^{\prime} 42.1^{\prime \prime}\right)$.

in all units by both low and high-angle normal faults. These normal faults are well exposed near Sirigas where they offset two large boudinaged marble layers (Fig. 8a). Two normal faults, occurring between Sirigas and Papouri and close to Kini, reach the critical size to be 
394 retrogressed rocks of Posidonia Subunit are in contact with the HP-LT blueschist- and 395 eclogite-facies metabasites of Kampos Subunit (Figs. 3, 8b). Quaternary slope deposits cover 396 this contact. Along the road between Finikas and Galissas, a west-dipping fault zone with 397 cataclasites and striations crops out for about 50 m-long, showing oblique normal kinematics 398 with top-to-the W-SW sense of movement (Figs. 8b, 8c, 8d, 8e). On top of this fault plane, a 399 3-4 m-thick brittle fault gouge is observed. Moreover, south of Finikas, we observed normal 400 faults trending N-S with similar top-to-the southwest kinematics (Fig. 8b, 8f). These two 401 outcrops characterize a 4 km-long late brittle normal fault, the Finikas-Galissas Fault (Figs. 3, $4028 b)$. 

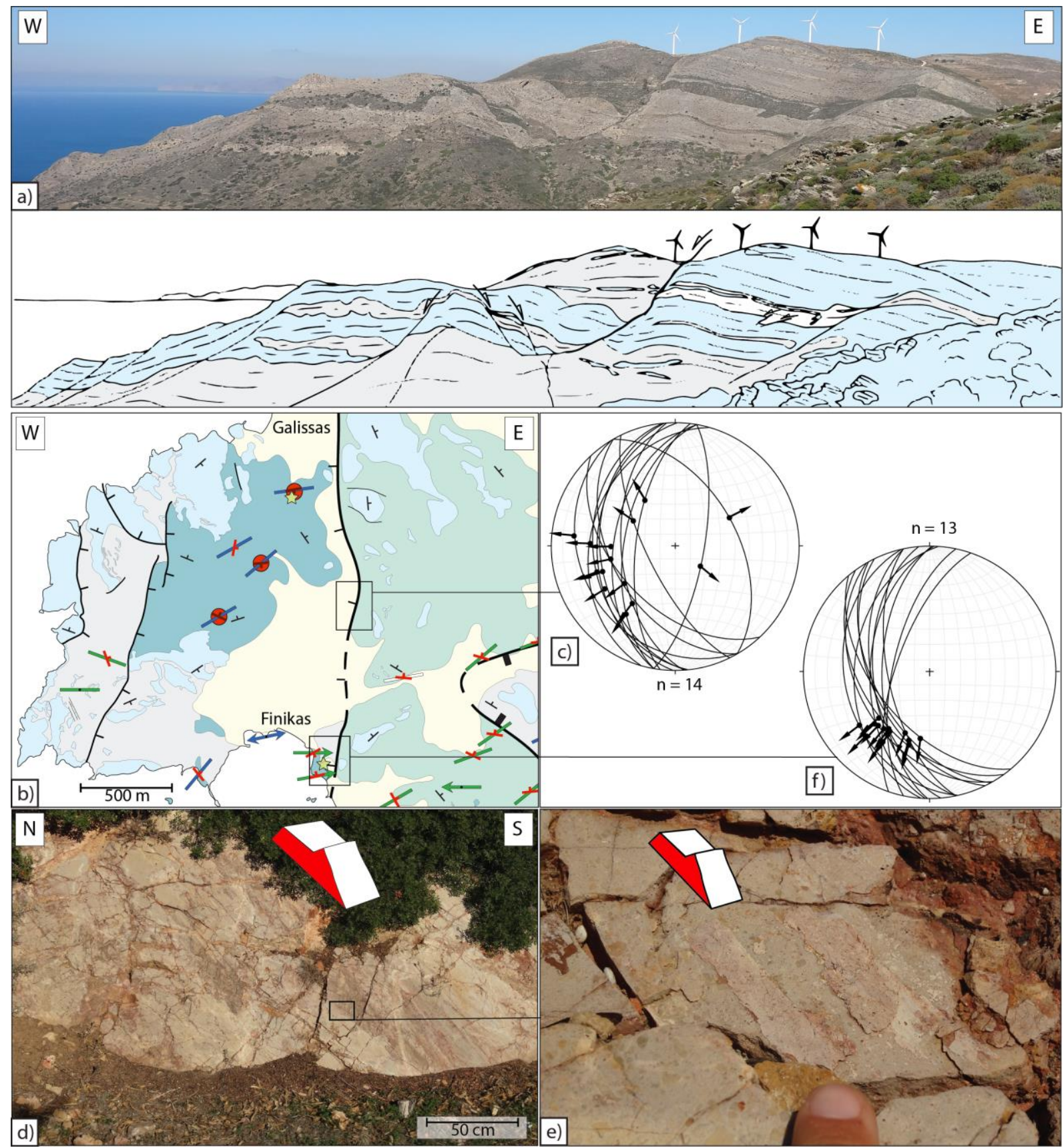

Figure 8: Field photographs of observed brittle normal faults. a) Panorama (Chroussa Subunit) showing coeval top-to-the east and west ductile-brittle to purely brittle normal faults. b) Zoom of the geological map showing location of outcrops along the Finikas-Galissas Fault. c) Associated stereogram showing measured brittle normal fault planes that indicate top-to-the W/SW kinematic. d) Brittle fault plane observed along the main road between Finikas and Galissas. e) Zoom on the striated fault plane showing the normal sense of motion. f) Stereogram showing brittle normal fault planes measured near Finikas village that indicate top-to-the southwest 
5) Geometry, kinematics and metamorphic conditions of the major contacts

If the Vari Detachment has already been described in previous works (Soukis and

419 Stöckli, 2013), some of the major contacts described below were so far either neglected (i.e.

420 Achladi-Delfini Shear Zone), or not fully understood in previous works. The new map, 421 supported by field data and satellite observation, allows us to identify their main 422 characteristics and role in the island overall architecture.

424 5.1) Posidonia-Chroussa subunits contact: the Achladi-Delfini Shear Zone

The Posidonia-Chroussa subunits contact is exposed between Achladi Cape and

427 Delfini (Fig. 9, see location on Fig. 3). In its southern limit, the trace of the shear zone can be 428 followed over more than $3 \mathrm{~km}$ in the landscape, shown by the non-coaxial deformation of marbles layers (Fig. 9a). Some marble layers are affected by brittle normal faults, while others are boudinaged and separated by ductile shear zones rooting in the contact between Chroussa and Posidonia subunits. Whatever the regime of deformation and the physical conditions that prevailed, ductile or brittle, clear top-to-the east deformation is observed in the form of a thick shear zone (Fig. 9a). Below, the intensity of greenschist-facies retrogression increases in the

434 vicinity of the shear zone, where metabasites are turned into chlorite-albite prasinites in which 435 former HP-LT imprint is not detectable in the field. For example, west of Cape Achladi along 436 the southern coast of the island, rocks of the Posidonia Subunit are strongly overprinted by 437 greenschist-facies parageneses. At the cape, a metaconglomerate of Posidonia Subunit 438 consisting of basic and calcitic pebbles embedded in heavily retrogressed metapelitic matrix 439 crops out just below the contact. Within this metaconglomerate, pebbles are ductilely sheared 440 with a top-to-the east kinematic (Fig. 9b). Structurally a few meters above, a ca. 20 m-long 
441 outcrop of preserved blueschist-facies metabasite is associated with eclogite boudins (Fig. 9c).

442 This sharp transition from well-preserved blueschists and eclogites above strongly retrograded

443 rocks below also supports the presence of a major shear zone between the Posidonia and

444 Chroussa subunits, named in this study the Achladi-Delfini Shear Zone.

445 Furthermore, the same contact between Posidonia and Chroussa subunits is exposed

446 around Delfini Bay that is bounded to the west by a small peninsula (Fig. 9d). Along a SW to

447 NE transect through Delfini peninsula, two blue- to greenschist-facies shear zones are 448 observed (Figs. 9d, 9e). Top-to-the east kinematic indicators such as shear bands, sigmoidal

449 pressure shadows on garnets or drag folds associated with crystallization of syn-kinematic 450 chlorite and albite are observed within the Delfini peninsula (Figs. 9f, 9g). These two 451 metamorphic transition zones, distant of ca. $500 \mathrm{~m}$, define the contact between Posidonia and 452 Chroussa subunits. These shear zones have each accommodated a part of the total 453 displacement and can be considered at large-scale as a single structure, the Achladi-Delfini 454 Shear Zone (Fig. 3).

455 Despite poorer outcrop conditions within the island, the trace of this contact was 456 followed by combining structural and metamorphic observations, looking especially for the 457 preservation of HP-LT minerals. These field observations were strengthened by detailed 458 analysis of aerial pictures. At map-scale, the resulting geometry of the Achladi-Delfini Shear 459 Zone shows a sinuous contact extending over $13 \mathrm{~km}$ through the island (Fig. 3). 

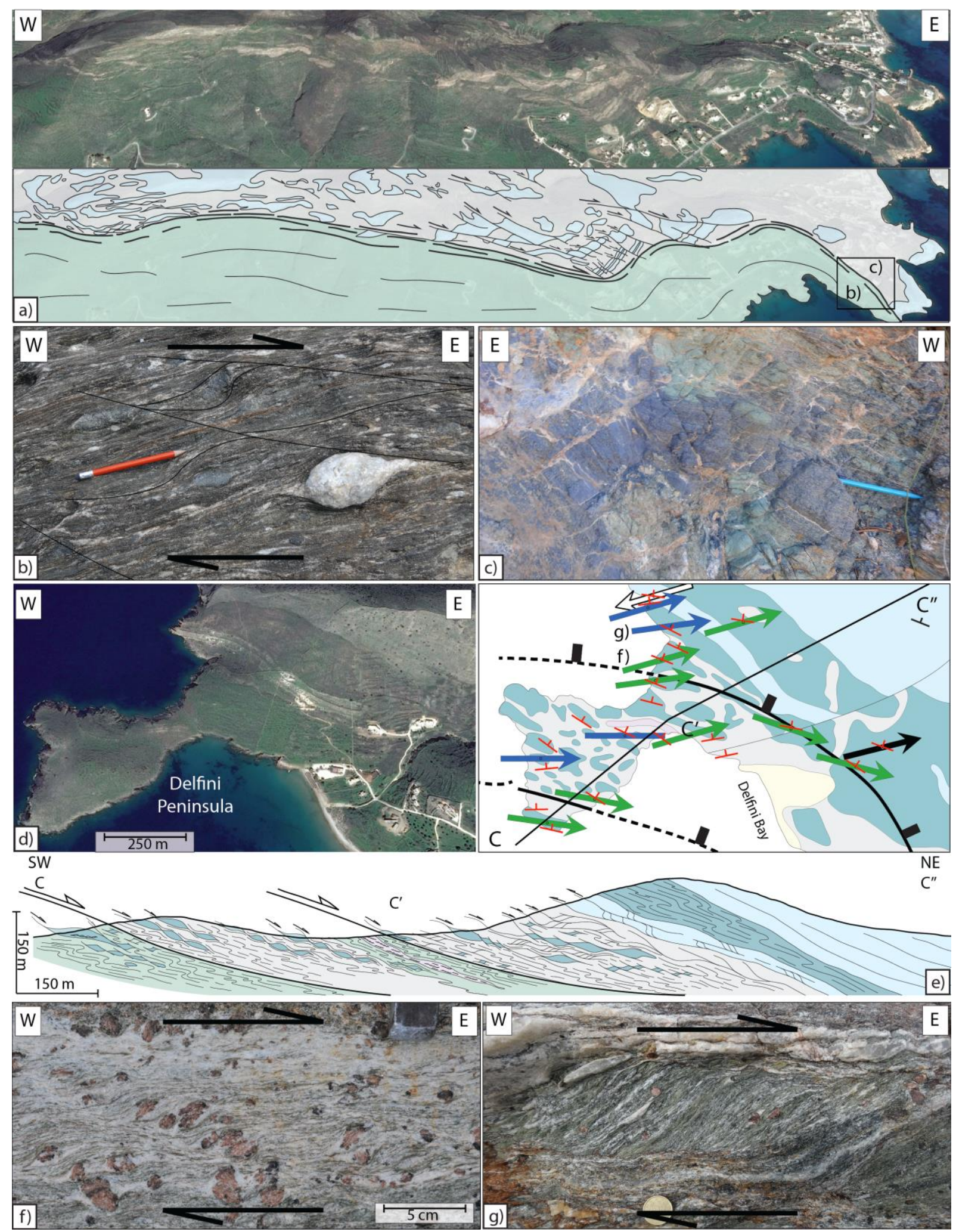

Figure 9: The top-to-the east Achladi-Delfini Shear Zone. a) Satellital image of the Achladi-Delfini Shear Zone observed above Achladi Cape and its interpretation showing top-to-the east sense of shear. b) Top-to-the east shearing in a greenschist metaconglomerate unit located just below the contact. c) Structurally few meters above, in the Chroussa Subunit, massive glaucophanites are observed with eclogitic boudins. d) Satellital image of the Delfini peninsula and its geological interpretation. e) Geological cross-section through the Delfini peninsula illustrating the architecture of the Achladi-Delfini Shear Zone. f) Top-to-the east kinematic indicators observed in retrogressed greenschist-facies rocks. g) Syn-blueschist top-to-the east shearing observed in the Chroussa Subunit. 
469 5.2) Chroussa-Kampos subunits contact: the Kastri and Lia Shear Zones

470

471 The contact between Chroussa and Kampos subunits is well exposed in the northern

472 part of the island, along the Kampos metabasite belt (Fig. 10; see also Keiter et al., 2004,

473 2011). This metabasic unit shows an E-W orientation and dips toward the north on the

474 western side. It strikes more N-S dipping westward in its eastern half (Fig. 10). The northern

475 and southern contact zones of the Kampos Subunit, i.e. the basal and roof contacts, are nicely

476 exposed along the coast, especially on the way to Lia Beach (Fig. 10).

477 


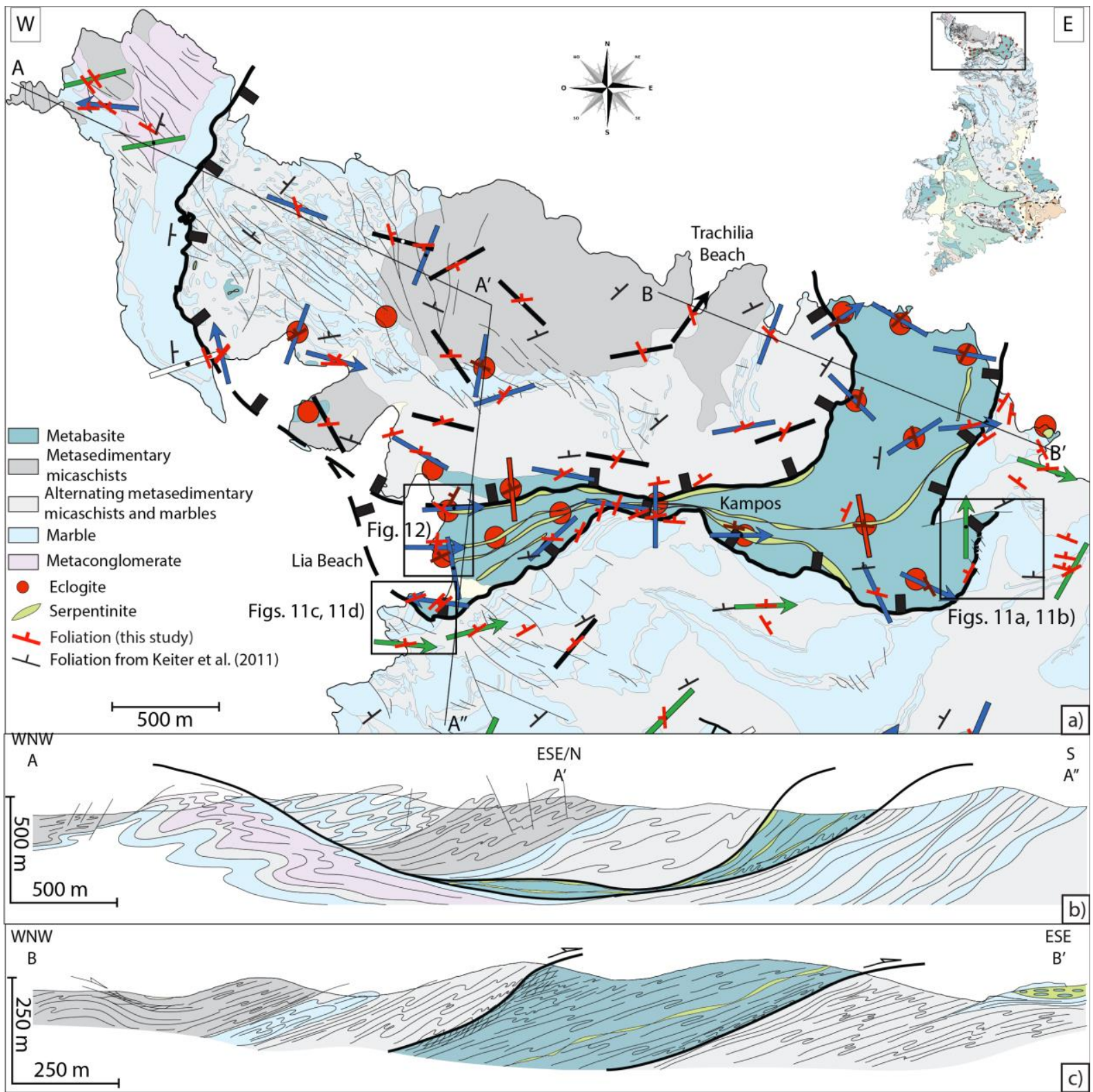

Figure 10: Geological architecture of the northern part of Syros. a) Geological map showing locations of crosssections and figures 12 and 13. b) Cross-section illustrating the organization and deformation of structures. Note that large shear zones surround the western part of the Kampos metabasite belt. c) Detailed cross-section of the eastern part of the Kampos metabasite belt.

The basal contact of Kampos Subunit with Chroussa Subunit can be seen in the boudinaged and sheared, some of them showing large-scale sigmoids (Fig. 11a). These structures define a large-scale top-to-the northeast shear zone, named in this study the Kastri Shear Zone. Just below the contact, tightly folded marble intercalations occur as a result of intense shearing along this major shear zone (Fig. 11b). In contrast to the Kampos Subunit 


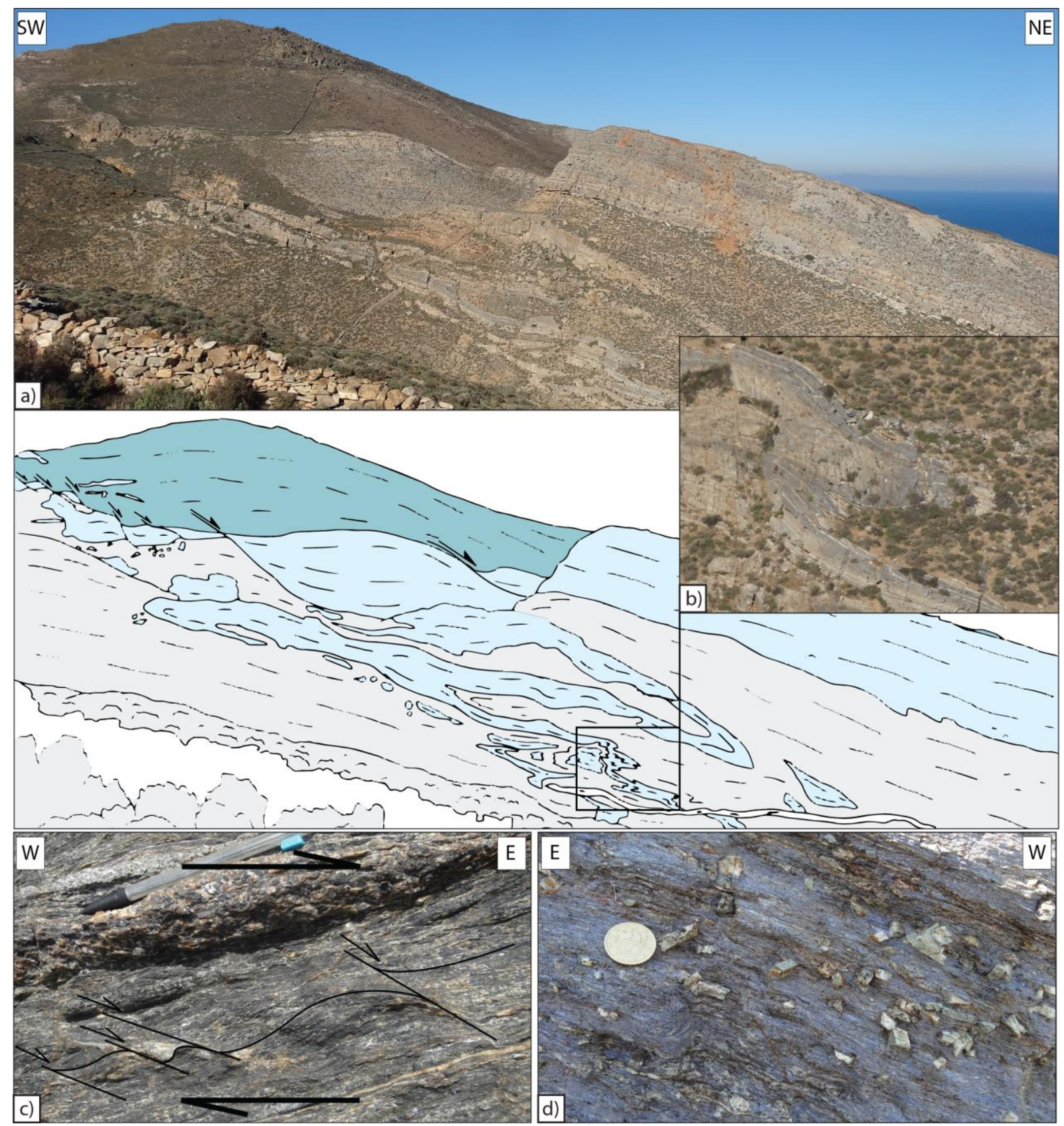

Figure 11: Basal contact of the Kampos metabasite belt: the Kastri Shear Zone. Pictures are located on the Fig.

496 12. a) Field view and its interpretation of the eastern part of the Kastri Shear Zone. Large-scale asymmetric 497 boudins of marble are observed in the contact zone and show top-to-the northeast sense of deformation. b) Zoom 498 showing the intense folding of black marbles below this contact. c) Directly below the contact, the Chroussa 499 Subunit is highly retrogressed and displays syn-greenschist top-to-the east sense of shear. d) High-pressure 500 glaucophanites bearing lawsonite pseudomorphs are well preserved up to the contact on Lia Beach. 
Although the Kampos Subunit composes the upper structural part of the CBU, a klippe 503 with a lithology similar to Chroussa Subunit is observed above the Kampos metabasite belt 504 (Fig. 10). The contact zone between this klippe and the roof of the Kampos metabasite belt 505 displays intense deformation and occurs between foliated serpentinite and metapelite (Figs. 506 12a, 12b). The foliation is parallel to the contact and is cut by a significant number of east507 dipping shear zones decorated with syn-kinematic glaucophanes (Figs. 12b, 12c, 12d). This 508 shear zone also shows asymmetrical boudins of metabasites included in a sigmoidal foliation 509 compatible with top-to-the east shearing deformation and folds with curved axes mostly 510 parallel to the stretching lineation, suggesting sheath folds (Figs. 12e, 12f). All these

511 structures define the existence of a major syn-blueschist top-to-the east shear zone located at 512 the roof of the Kampos metabasite belt, which we called the Lia Shear Zone. 

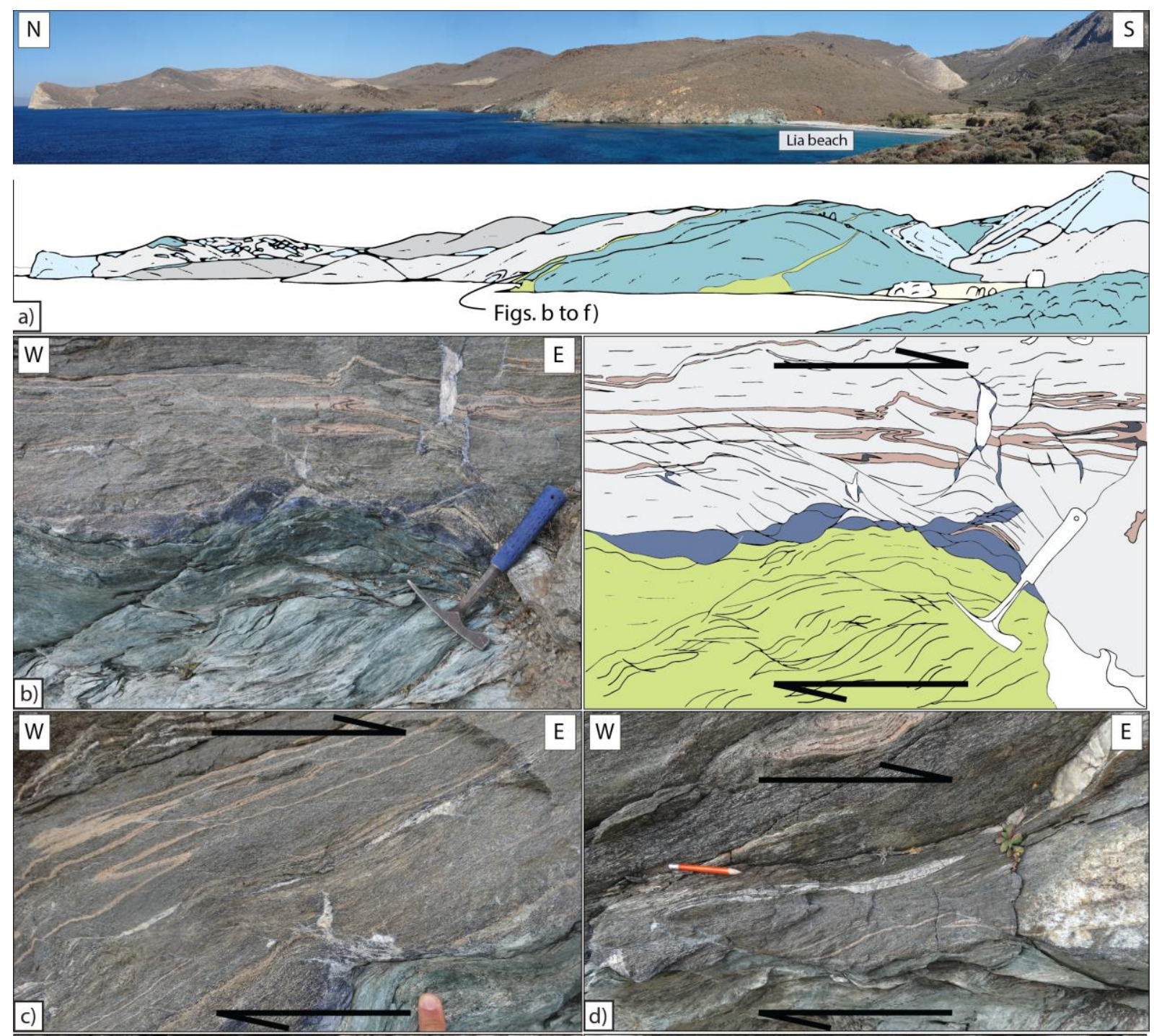

c)

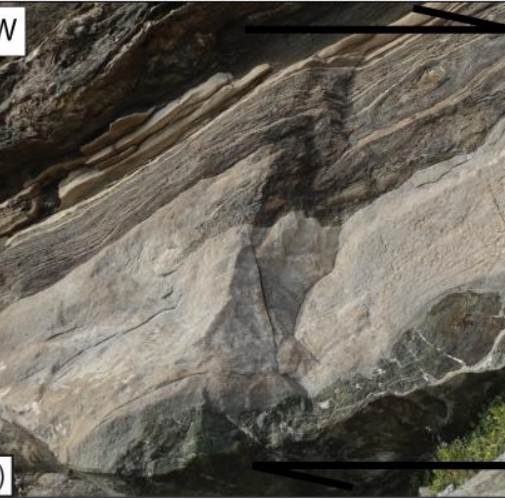

d)

sents

Figure 12: Roof contact of the Kampos metabasite belt. a) Field view of the western part of the Kampos metabasite belt and its geological interpretation. b, c, d) This contact is characterized by serpentinites below and 518 metabasite layer included in a sigmoidal foliation compatible with top-to-the east shearing deformation. f) Folds 519 with curved axes sub-parallel to the stretching lineation and showing closed contour building the typical eye520 structure of sheath folds. 
The contact between the CBU and Vari Unit is a debated topic in literature. The contact itself is hidden by Quaternary deposits and probably affected by late normal faults. However,

527 field investigations into the footwall unit, i.e. the CBU, allow proposing new arguments on 528 the internal architecture of the Vari Detachment from bottom to top as it crops out from Cape 529 Katerghaki to Vari (Fig. 13).

Below the contact, trending parallel to the stretching lineation, the whole section is characterized by a shallow northeast-dipping foliation showing that Vari Unit structurally overlain Kampos Subunit (Figs. 13a, 13b). As the rest of Kampos Subunit, these mafic rocks preserve HP-LT metamorphic parageneses such as eclogites and blueschists (see also Trotet et al., 2001a), and display a gradient of retrogression from eclogite- to blueschist-facies toward the contact. Indeed, the southwestern part of Cape Katerghaki (see location on Fig. 3) is composed of 10 m-thick massive eclogite bodies, which are more and more retrogressed in the blueschist-facies toward Vari Unit. All along this gradient, rocks show evidence of syneclogitic stretching reworked by syn-blueschists top-to-the east ductile shearing with HP-LT

539 minerals such as glaucophanes decorating shear zones (Figs. 13c, 13d). South of Fabrika 540 beach, structurally 20-30 m below the contact, a metaconglomerate composed of eclogitized 541 mafic pebbles comprised within a marble matrix show top-to-the east sense of shear (Fig. 13e).

542 Conjugate northeast-striking normal faults displace the inherited high-pressure structure by a 543 few tens of meters. This may be due to conjugate normal faults (Figs. 13a, 13b). Just above the contact and within the Vari Unit, mylonitic greenschists are observed, 545 displaying only greenschist-facies metamorphism without any evidence of prior HP-LT stage, 546 in contrast with the greenschist-facies metamorphic rocks observed in the bulk of the CBU. 547 These rocks are strongly foliated and top-to-the E/NE shear criteria are observed such as 
548 sigmoidal pressure shadows on pyrite showing top-to-the east kinematic in the north of

549 Fabrika beach, and top-to-the northeast shear bands south of Azolimnos village. On top of

550 these greenschist-facies mylonites, the Vari orthogneiss shows a plano-linear ductile fabric

551 with a stretching lineation oriented $\mathrm{N} 70^{\circ} \mathrm{E}$, intercalated in some places with fine-grained

552 amphibolites. This unit is affected by brittle deformation, expressed as several $10 \mathrm{~m}$-thick

553 zones of cataclasites cutting through the orthogneiss (Fig. 13f; see also Soukis and Stöckli,

554 2013). Several E-W trending normal faults are observed in this area, cutting across the

555 orthogneiss foliation at distance from the contact with the CBU, at variance with Philippon et

556 al.'s (2011) interpretation of the regional structure. Our interpretation is confirmed at larger

557 scale. Philippon et al. (2011) correlated the Vari basement lithologies with the so-called

558 gneiss observed in the lower part of our Posidonia Unit, but we have seen that Posidonia Unit

559 has seen the same peak of metamorphism as the other CBU of Syros with the local

560 preservation of blueschists- or eclogite-facies metabasites while the Vari Unit has never been

561 through HP-LT conditions. 


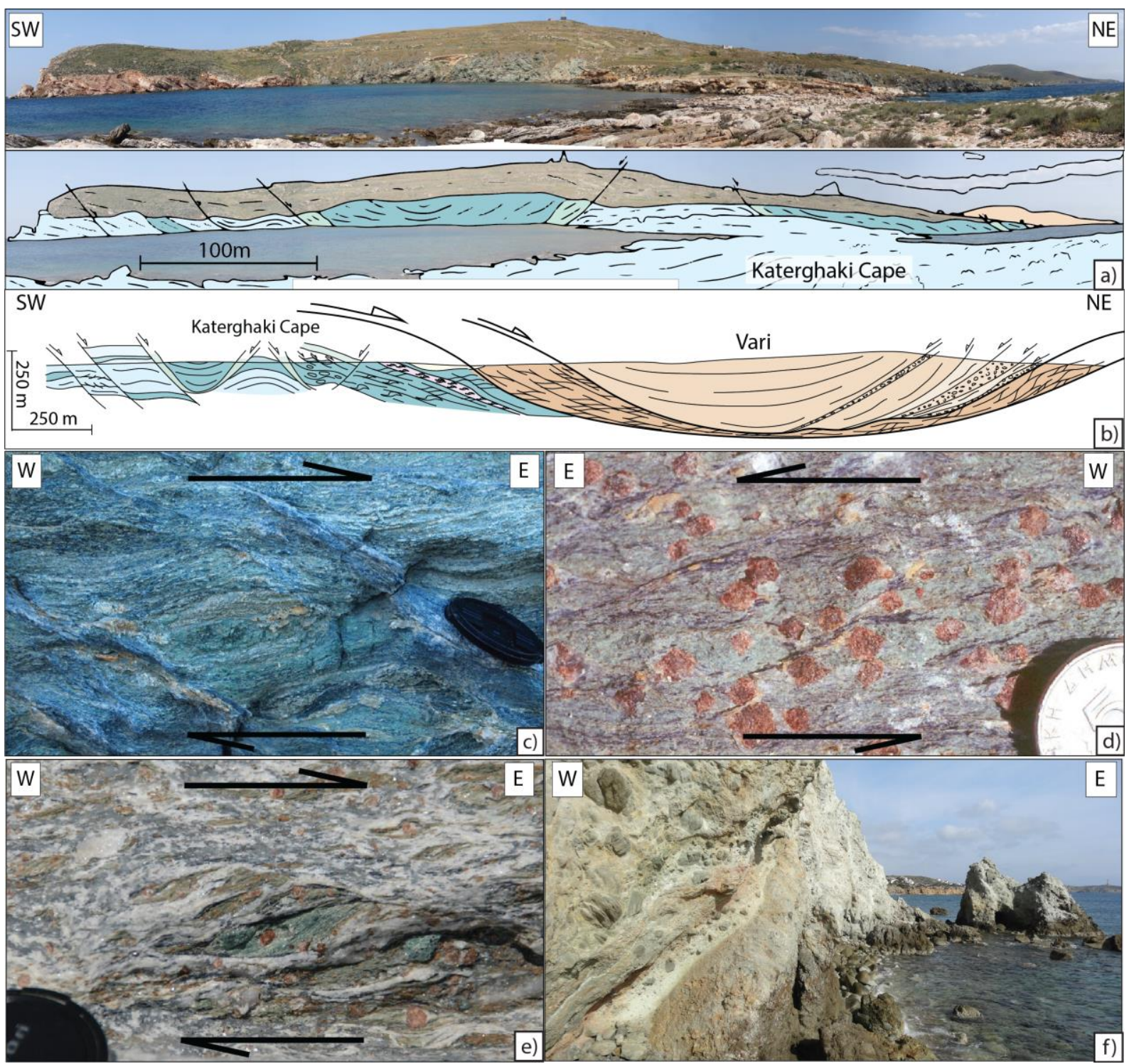

574 lithological point of view, its structural interpretation is drastically different. This is

Figure 13: The Vari Detachment. a) Field photography showing that the CBU is structurally below the Vari Unit. b) Cross-section showing the architecture of the Vari Detachment and its top-to-the east sense of motion. c, d, e) Below the Vari Detachment, rocks of the CBU display a significant number of top-to-the east syn-blueschist shear bands affecting eclogites. f) Large-scale cataclastic zones observed upon the Vari Detachment within the gneiss of Vari.

6) Discussion

particularly evident in the analysis of large-scale geometries, unit and subunit subdivisions 
576 and in the analysis of metamorphic record, which allowed us to identify several orders of

577 shear zones due to strain localization.

579 6.1) What is left of the original nappe structure of the Cycladic Blueschist Unit?

We have recognized three distinct tectonic subunits composing the CBU in Syros,

582 from top to base, the Kampos, Chroussa and Posidonia subunits, all resting structurally below

583 the Vari Unit, which shows no evidence of HP. These subunits are characterized by their

584 lithology and predominant metamorphic facies as seen in the field. All three subunits have 585 seen the P-T conditions of the eclogite-facies but they have been subjected to different 586 degrees of retrogression during exhumation. Following our observations, we propose a new 587 metamorphic map based upon the study of predominant metamorphic facies, as well as on 588 kinematic indicators and their relation to metamorphic parageneses (Fig. 14). This map, where 589 colors correspond to the predominant metamorphic facies, displays the first-order distribution 590 of the main parageneses.

591 The recognition of remains of eclogite within all three subunits implies that Kampos,

592 Chroussa and Posidonia subunits have all undergone a HP-LT metamorphic event in the 593 eclogite-facies. It ensues that local blueschist- or greenschist-facies rocks abundance is 594 retrograde. The degree of retrogression, whether it occurred under blueschist and/or 595 greenschist metamorphic conditions, is entirely different. Retrogression increases from top to 596 bottom of the CBU, which points to important differences in the P-T-time evolution of the 597 different subunits during exhumation, as previously proposed by Trotet et al. (2001b). The 598 imprint of deformation during exhumation has been different in each of these subunits, 599 intense in the lowermost Posidonia Subunit (where the entire subunit has been sheared and 600 pervasively retrogressed), weaker in the uppermost Kampos Subunit (where blueschist- and 
601 then greenschist-facies deformation is localized along preferential shear zones). The Achladi-

602 Delfini Shear Zone best shows this contrast. These features are similar to those observed on

603 Sifnos (Roche et al., submitted) and seem characteristic of the large-scale structure acquired

604 by the CBU within the subduction channel before those rocks were reworked by greenschist-

605 facies deformation during Oligocene to Miocene extension. We now discuss the

606 tectonometamorphic evolution of the subunits within the subduction channel.

607 The apparent inverse metamorphic gradient defined by the transition from the 608 preserved high-pressure Kampos Subunit to the strongly retrograded Posidonia Subunit raises

609 petrological questions. Indeed, very different P-T histories were so far published for Syros in

610 terms of peak P-T conditions and shape of retrograde P-T path (Fig. 1b). Exhumation

611 scenarios with a single retrograde P-T path for the whole CBU (Keiter et al., 2004, 2011;

612 Schumacher et al., 2008) cannot explain the different degrees of retrogression observed in the

613 CBU. Maximum P-T conditions around $15 \mathrm{kbar}$ and $500^{\circ} \mathrm{C}$ (Schumacher et al., 2008) just

614 fringe the eclogite-facies (Fig. 1b) while eclogites are abundantly observed on Syros as well

615 as on Sifnos (Trotet et al., 2001a). To justify these apparent contradictions, Schumacher et al.

616 (2008) hypothesized that eclogites of Syros are the product of an earlier metamorphic event

617 and were juxtaposed with the rest of the CBU by tectonic contacts. As result of our 618 observations, the presence of eclogite boudins and lenses in all subunits cropping out on Syros,

619 except the Vari Unit, does not fit the interpretation of Schumacher et al. (2008). An 620 alternative explanation would be that the glaucophane-bearing marbles studied by 621 Schumacher et al. (2008) were formed during the retrograde path in P-T conditions for which 622 this assemblage is in equilibrium or that the amphibole mineralogy and stability is chemically 623 buffered by the lithology. Indeed, much of the blueschist-facies parageneses on Syros are syn624 kinematic and show top-to-the east sense of shear and clearly postdates the eclogite-facies. 625 Consequently, our structural observations best fit the petrological analyses of Trotet et al. 
626 (2001b), for whom all subunits of the CBU attained the same metamorphic peak in the P-T

627 field of eclogite-facies, and followed different retrograde P-T paths, leading to different grade

628 of retrogression in the CBU during the continuous activity of large-scale top-to-the east shear

629 zones between Kampos, Chroussa and Posidonia subunits all over the exhumation (Fig. 1b).

630 According to this interpretation, the tectonic history and the metamorphic path to the surface

631 differ from the one envisaged by Keiter et al. (2004, 2011), who suggested rigid block

632 exhumation mechanisms of the whole CBU as a single block. It remains true however that

633 deformation progressively localized during exhumation along shear zones and that entire parts

634 of the islands escape from the low-temperature deformation, these domains are those where

635 the HP-LT parageneses are best preserved, as discussed in the next section. 


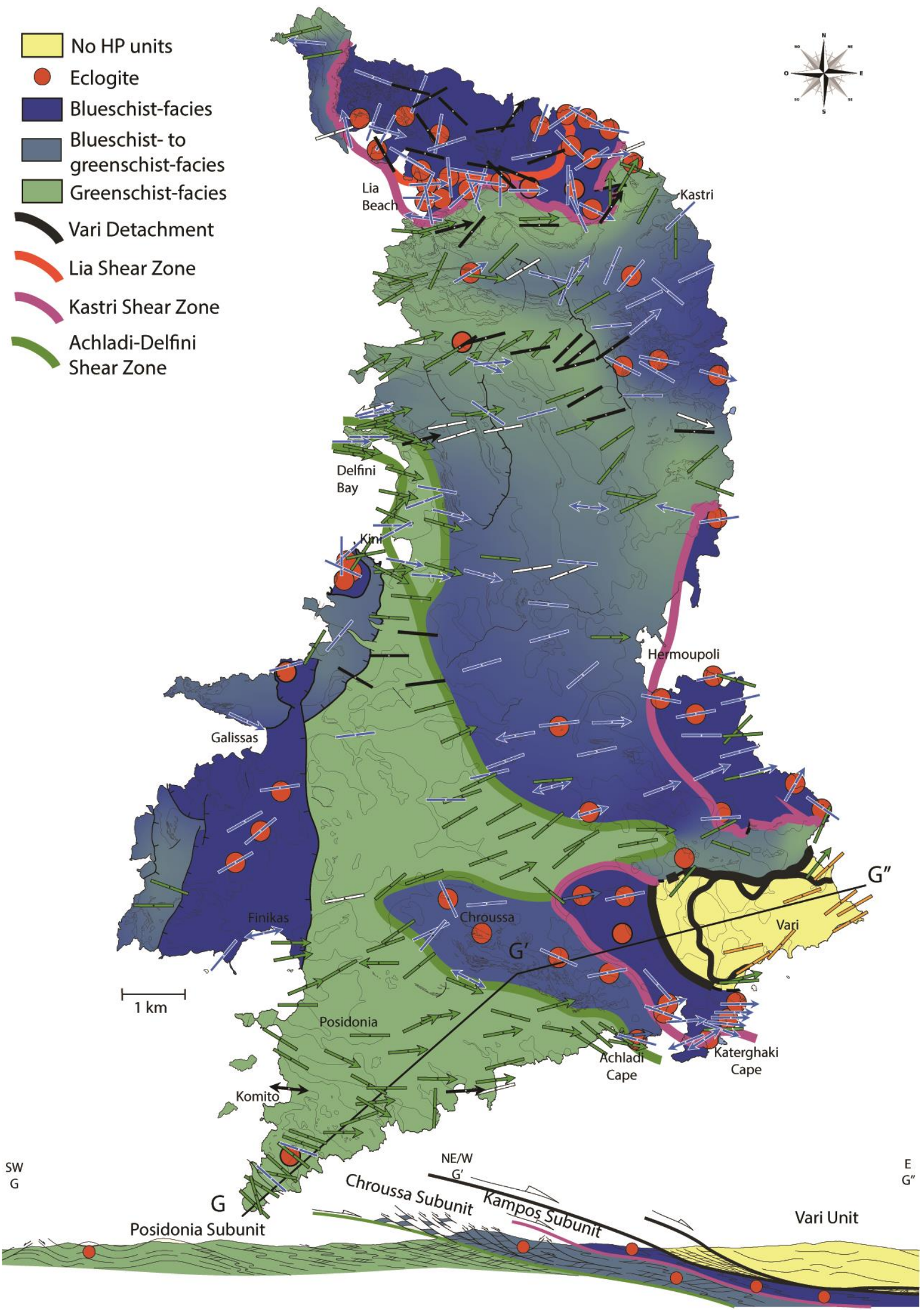

637 Figure 14: New metamorphic map of Syros showing an apparent inverse metamorphic gradient. The G-G" cross-

638 sections represent a synthetic view over the overall tectonometamorphic structure of Syros. The architecture of

639 the CBU is subdivided here in three subunits separated by large-scale shear zones. Note that in our interpretation,

640 the Vari Detachment juxtaposed with a top-to-the east motion the CBU and the uppermost Vari Unit. 
6.2) Prograde or retrograde deformation?

A number of previous structural studies reported that prograde deformation is

644 observed in Syros (Rosenbaum et al., 2002; Keiter et al., 2004, 2011; Philippon et al., 2011).

645 Some of these studies postulated that this deformation took place just before or during peak

646 metamorphism with no or only local retrograde deformation (Rosenbaum et al., 2002; Keiter

647 et al., 2004, 2011). Three main arguments are presented in the literature. 1) The observation 648 of deformed pseudomorphs of lawsonite: Philippon et al. (2011) noted that these

649 pseudomorphs are always sheared with top-to-the S/SW kinematics and they correlated this

650 sense of shear with subduction-related prograde thrusting. 2) The presence of large thrust

651 zones, often described at the base of metabasic units. 3) The widespread preservation of 652 aragonite pseudomorphs supports the view that no pervasive retrograde deformation occurred 653 subsequently to the main prograde to peak metamorphism deformation event. The frequent 654 presence of aragonite pseudomorphs in the Kampos Subunit, for instance in 655 metaconglomerates, indeed shows that no significant deformation occurred at those places in 656 the greenschist-facies and that parts of this subunit were exhumed as rigid bodies once they 657 had exited blueschist-facies conditions (Schumacher et al., 2008).

Our study shows that the three subunits composing the CBU are each separated by 659 top-to-the E/NE shear zones (Figs. 3, 14). This top-to-the E/NE deformation event observed 660 within the entire volume of the CBU on Syros also affects lawsonite pseudomorphs (Fig. 6b) 661 in contradiction with Philippon et al.'s observations (2011). Therefore, these structures are not 662 only markers of prograde deformation, but also characterize early retrograde deformation. 663 Indeed, taking into account the new lawsonite + glaucophane out reaction calculated for Fe$664 \mathrm{Mg}$ end-member at $\mathrm{XCO}_{2}=0,01$ (Schumacher et al., 2008), and the P-T path of Trotet et al. 
665 (2001b), it appears that lawsonite could have been sheared with top-to-the east sense of shear 666 during the first exhumation stages (Fig. 1b).

668 interpreted differently in previous studies. On one hand, Trotet et al. (2001a) describe this

669 contact as a ductile detachment. For these authors, this contact is marked in the field by an 670 apparent metamorphic gap between retrograded greenschist-facies rocks below the 671 detachment and preserved eclogite- and blueschist-facies above (Fig. 2a). On the other hand, 672 Keiter et al. (2004, 2011) and Philippon et al. (2011) described this contact as a large prograde

673 thrust related to the subduction phase. Although Keiter et al. (2004) challenged the existence 674 of a sharp metamorphic transition through this contact, we confirm this observation of Trotet 675 et al. (2001a). Indeed, the contact zone is clearly marked by retrogression of the upper part of 676 the underlying Chroussa Subunit over a 100 m-thick greenschist-facies shear zone. Moreover, 677 all shear criteria observed within this shear zone are top-to-the E/NE, in agreement with syn678 greenschist retrograde sense of shear observed within the Achladi-Delfini Shear Zone deeper 679 down in the CBU. This does not preclude the possibility that the Kampos-Chroussa subunits 680 contact is originally a thrust as it superimposes the Kampos Subunit, which is mostly 681 ophiolitic, on top of the Chroussa Subunit, which is mostly made of metasediments. Our 682 interpretation is that this thrust has been later reactivated as a major top-to-the east shear zone 683 during exhumation. In the same way, we interpret the klippe of Chroussa Subunit, which is 684 structurally positioned above the Kampos metabasite belt (Fig. 10), as thrusted onto the 685 Kampos Subunit during the late prograde phase of subduction or during the early phase of 686 exhumation. Indeed, this klippe corresponds lithologically to the Chroussa Subunit but shows 687 only eclogite to blueschist parageneses as the Kampos Subunit (Fig. 14). Our observations 688 show that this thrust was reactivated only in the blueschist-facies forming the Lia Shear Zone 
689 (Fig. 12). Then the klippe and the Kampos metabasite belt may have followed, as a single unit, 690 the same exhumation history. In agreement with Trotet et al. (2001a), one of the major results of our study is the

692 observation of a pervasive continuum of top-to-the E/NE deformation from P-T conditions of 693 the metamorphic peak (eclogite-facies) to late stages of retrogression in the blueschist- and 694 then greenschist-facies. In contrast to Rosenbaum et al. (2002), and Keiter et al. (2004, 2011), 695 we conclude that a large part of the deformation in Syros was acquired during exhumation and 696 that this deformation was heterogeneously distributed and preferentially localized along extensional shear zones.

However, it is also clear that locally, criteria of prograde or peak-metamorphism 699 deformations are preserved. Different structures are most notably inconsistent with a 700 pervasive top-to-the E/NE retrograde shearing. First, the orientation of stretching lineations is 701 distinctly scattered in subunits best preserving eclogite and blueschist-facies parageneses (i.e. 702 Chroussa and Kampos subunits; Figs. 3, 4). Indeed, a group of N-S oriented lineations and 703 top-to-the S/SW kinematic indicators, already observed by Philippon et al. (2011), can be 704 found in Kampos Subunit. Then, at a larger-scale, the N-S orientation of the Kampos metabasite belt (see Keiter et al., 2004, 2011) is inconsistent with E-W oriented deformation and top-to-the E/NE sense of shear. All these structures appear to be related with a N-S

707 oriented shearing event and not with the retrograde top-to-the E/NE continuum of 708 deformation described in this study. A plausible explanation would be that these structures 709 were acquired during an early N-S oriented prograde event in the subduction channel, leading 710 to formation of large thrust planes between units that are now found preserved in the highly 711 metamorphic Kampos and Chroussa subunits. This interpretation is consistent with top-to-the 712 S/SW prograde sense of shear described by Philippon et al. (2011). Such peak-metamorphic 713 structures were later reactivated as weak contact zones during exhumation, within a top-to-the 
714 E/NE non-coaxial regime progressively localizing strain toward the lower structural parts of

715 the CBU. These features are discussed in the context of the heterogeneous localization of

716 deformation during exhumation of the CBU.

718 6.3) Localization of deformation during exhumation

The roof contact of the Kampos metabasite belt is only marked by syn-blueschist

721 deformation, showing that this shear zone was deactivated early in the exhumation process,

722 and that the deformation localized progressively in the basal contact of Kampos Subunit,

723 which is characterized by syn-greenschist deformation. In contrast with Posidonia Subunit,

724 Chroussa Subunit is not totally retrogressed in the greenschist-facies and shows large portions

725 characterized by the predominance of blueschist-facies parageneses. Once again, this feature

726 illustrates the progressive localization of deformation during exhumation toward the base of

727 the CBU, i.e. toward Posidonia Subunit. Finally, the Achladi-Delfini Shear Zone is currently

728 characterized by syn-greenschist deformation that has overprinted the entire volume of

729 Posidonia Subunit.

730 Progressive localization of deformation toward the base of the CBU in Syros during 731 exhumation is linked with a younging of apparent ages towards the south, from Kampos (45-

$73250 \mathrm{Ma}$, syn-orogenic period) to Posidonia subunits (20-35 Ma, post-orogenic period), 733 especially shown by ${ }^{40} \mathrm{Ar} /{ }^{39} \mathrm{Ar}$ and $\mathrm{Rb} / \mathrm{Sr}$ data on white micas (Fig. 2b; Maluski et al., 1987;

734 Tomaschek, et al., 2003; Putlitz, et al., 2005; Huet, 2010; Bröcker et al., 2013). A possible

735 explanation would be that structurally downward strain localization leads to partial resetting 736 of isotopic systems or even recrystallization in the lowermost units. This migration of 737 deformation could be enhanced by different factors such as intense fluid circulations in the 738 basal part of the CBU and/or increased thermal influx at the base of the metamorphic pile 
740 2001b). This localization could be also linked to the different lithologies composing the CBU

741 on Syros, less and less resistant to deformation toward the base, passing from massive

742 metabasite in Kampos Subunit to a succession of thick marble layers and metapelites in

743 Chroussa Subunit and finally metapelites in Posidonia Subunit. During cooling of

744 metamorphic units, this inherited rheological heterogeneity may have enhanced the downward

745 localization of deformation toward the weak rheological units. So, while Posidonia Subunit

746 has been deformed until the P-T conditions of the greenschist-facies, the Kampos Subunit and

747 parts of the Chroussa Subunit have been only deformed during the first steps of exhumation.

748 This participated to the local preservation of prograde markers of deformation seen today,

749 allowing detailed petrological and structural information to be retrieved on the prograde

750 subduction-related phase of deformation.

752 6.4) Thrusting, exhumation and extension

The contacts between Kampos, Chroussa and Posidonia subunits have a polyphase

history. The first stage corresponds to the stacking of units by thrusting (i.e. nappe stacking), probably during the prograde evolution and at the pressure peak. A limited number of outcrops suggest that the sense of shear was toward the south during this first episode (Philippon et al., 2011). The main evidence of thrusting is that the uppermost HP-LT Kampos

759 Subunit is mostly made of ophiolitic material, while the lowermost Posidonia Subunit is rich

760 in metapelites that may have been deposited over a continental basement (Keiter et al., 2004;

761 2011; Schumacher et al., 2008; Philippon et al., 2011). In a second stage, the contacts were

762 reactivated during the retrograde evolution and exhumation, via a top-to-the east shearing

763 deformation, localized along the main contacts or distributed within the whole Posidonia 
764 Subunit. This continuum of top-to-the east shear thus encompasses two major periods of the geodynamic evolution of the Aegean: (1) The Eocene construction of the Hellenides nappe stack and HP-LT accretionary complex of the CBU; (2) the Oligocene to Miocene extension leading to crustal thinning and formation of the Aegean Sea in the back-arc region of the Hellenic subduction. The first period corresponds to exhumation of the CBU within the subduction channel (syn-orogenic exhumation, Jolivet et al., 2003; Jolivet and Brun, 2010), and the second stage to the formation of metamorphic core complexes of the Cyclades (postorogenic extension, Huet et al., 2011).

6.5) The Vari Detachment: an example of a subduction channel roof

Several studies describe the existence of the Vari Detachment on Syros, juxtaposing the Vari Unit above the CBU (Trotet et al., 2001a; Rosenbaum et al., 2002; Ring et al., 2003; Jolivet et al., 2010; Keiter et al., 2011; Soukis and Stöckli, 2013). It is also suggested that this detachment reappears on the neighboring island of Tinos (Maluski et al., 1987; Patzak et al., 1994; Jolivet et al., 2010; Soukis and Stöckli, 2013). This assumption is based on similar

780 structural and metamorphic features of the footwall and hangingwall of the detachment outcropping in each island. On the other hand, Philippon et al. (2011) drastically revised the interpretation of this contact, repositioning the Vari Unit below the CBU. According to them, 783 these rocks have to be correlated with the Cycladic Continental Basement cropping out in the 784 southern part of the Cyclades (cf. Huet et al., 2009; Augier et al., 2015). On the contrary, we 785 demonstrated here, that clear field evidences support the original interpretation putting the 786 Vari Unit on top of the CBU (Figs. 13a, 13b). The Vari Detachment is generally considered as 787 responsible for the exhumation of the CBU (Trotet et al., 2001a; Jolivet et al., 2010; Soukis 788 and Stöckli, 2013). Trotet et al. (2001a, 2001b) and Jolivet et al. (2010) argued that the Vari 
789 Detachment has accommodated part of the exhumation since the syn-orogenic period, 790 whereas Ring et al. (2003) conclude that this structure only allowed the final exhumation of 791 the CBU. Ring et al. (2003) obtained different retrograde cooling paths at the footwall and at 792 the roof of the Vari Detachment with fission-tracks data on apatite and zircon gathered on 793 Syros (Fig. 2b) and Tinos. From their results, they derive that intra-arc distributed extension 794 caused only the final 6-9 $\mathrm{km}$ of vertical exhumation, and they conclude that the Vari 795 Detachment was characterized by fast extension but caused little exhumation. But this 796 detailed study is based upon fission-track data, which put only T-t constraints on the final 797 parts of exhumation. Our structural observations show that the top-to-the E/NE deformation 798 affecting the rocks located at the footwall of the Vari Detachment started in eclogite to 799 blueschist P-T conditions and evolved progressively toward the conditions of the greenschist800 facies. Cataclastic deformation observed in the Vari Detachment testifies that this detachment 801 has continued to operate in brittle conditions, but not that this detachment started in brittle 802 conditions as asserted by Ring et al. (2003). Huet et al. (2009) and Jolivet et al. (2010) 803 hypothesized that the Vari Detachment represents the Eocene roof of the subduction channel. 804 Then, with the Oligocene to Miocene southward slab retreat, the Vari Detachment was 805 transferred in a back-arc position in the Late Miocene as attested by its present position.

807 6.6) Tectonometamorphic evolution of a subduction channel

808 Integrating the above presented and discussed new observations with the one available

810 in literature, we propose a new tectonometamorphic evolution sequence. This scenario is 811 divided in four steps:

1) From the early Paleocene (65 Ma) to the early Eocene (50 Ma): 
813 From the end of the Cretaceous, the Apulian continental block subducted below the southern

814 margin of Eurasia (Jolivet and Brun, 2010). During this N-S oriented subduction phase, the

815 Hellenic nappe stack was progressively constructed. The Pindos oceanic domain probably

816 started to subduct around $55 \mathrm{Ma}$ (Menant et al., 2015) forming at depth the CBU (Bonneau

817 and Kienast, 1982; Jolivet and Brun, 2010). Between 55 and $50 \mathrm{Ma}$, CBU rocks were strongly

818 deformed, forming the observed N-S trending stretching lineation, resulting in the thrusting of

819 subunits such as the Kampos Subunit with a resultant top-to-the S/SW sense of shear

820 associated with prograde shear zones (Philippon et al., 2011) and large-scale open folds

821 (Keiter et al., 2011; see also Roche et al., submitted, for Sifnos Island).

2) From the early Eocene (50 Ma) to the early Oligocene (35-30 Ma):

823 The CBU started to exhume, following an initial cold retrograde P-T path able to preserve

824 HP-LT parageneses. Ductile shear zones associated with syn-blueschist top-to-the east sense

825 of shear accommodated this exhumation below the Vari Detachment that represented the roof

826 of the subduction channel. During this syn-orogenic phase, deformation started to localize at

827 the interface between large lithological units, probably along former thrusts, delimiting the

828 subunits detached from the overlying plate. During this period, a top-to-the south thrust,

829 observed on Ios Island and located at the base of the CBU (Huet et al., 2009), was active and

830 exhumation of the CBU was accommodated within the subduction channel of a slowly

831 retreating subduction zone while the thrust front was propagated southward (Jolivet et al.,

832 2003; Brun and Faccenna, 2008, Jolivet and Brun, 2010; Ring et al., 2010).

833 3) From the early Oligocene (30-35 Ma) to the early Miocene (23-19 Ma):

834 A drastic change in kinematic boundary conditions occurs at 30-35 Ma with a decrease of the 835 absolute northward motion of Africa and the southward retreat of the subducting slab (Jolivet 836 and Faccenna, 2000). This drastic change marks the transition from syn-orogenic exhumation 837 to post-orogenic extension and the formation of the Aegean Sea. The post-orogenic 
838 extensional regime is still characterized by top-to-the E/NE sense of shear as observed in the

839 Achladi-Delfini Shear Zone. During exhumation, deformation progressively localized in

840 lower structural levels of the CBU where retrogression is almost complete.

4) From the Early Miocene (23-19 Ma) to the present:

842 The final exhumation of the CBU is first controlled by ductile-brittle normal faults and finally

843 by purely brittle normal faults. The Achladi-Delfini Shear Zone displays ductile-brittle

844 deformation with top-to-the E/NE sense of shear, like some outcrops in the Chroussa Subunit.

845 Large-scale brittle normal faults can finally affect the exhumed units such as the $4 \mathrm{~km}$

846 Finikas-Galissas Fault, which juxtaposes well-preserved eclogite- to blueschist-facies rocks

847 with strongly retrogressed units (Figs. 3, 8b).

849 7) Conclusion

In this study, new geological and metamorphic maps and cross-sections of Syros have

852 been proposed, described and discussed. Field mapping combined with structural and

853 petrological observations allow us to subdivide the CBU into three subunits, Kampos,

854 Chroussa and Posidonia subunits, separated by major ductile shear zones. Eclogite is found 855 within all three subunits. This implies that, despite their entirely different degree of retrogression (from eclogite at the top to greenschist at the base), the subunits have undergone

857 the same HP-LT metamorphic peak in eclogite-facies, pointing to important differences in P-

858 T-time evolution during exhumation. Large-scale ductile shear zones delimiting the subunits

859 record a multi-stage structural evolution. They may have formed during burial with the 860 development of a currently $\mathrm{N}-\mathrm{S}$ trending eclogite to blueschist stretching lineation 861 accompanied by top-to-the S/SW sense of shear. From the P-T conditions of the metamorphic 862 peak and during exhumation, the contacts were reactivated as top-to-the east ductile 
863 extensional shear zones. New observations of the Vari Detachment, which juxtaposes the low-

864 pressure Vari Unit onto the CBU, show consistent top-to-the-east shear sense. We infer that,

865 after the prograde top-to-the S/SW deformation, the CBU was exhumed by an overall top-to-

866 the east shearing all the way from the depth of the eclogite-facies to the greenschist-facies and

867 finally, into the brittle crust. During exhumation, deformation progressively localized

868 downward in the CBU, along several large-scale ductile shear zones, allowing preservation of

869 earlier HP-LT structures and metamorphic parageneses.

870 This study brings new insights on the tectonometamorphic evolution of a subduction

871 channel, showing progressive strain localization, during both the prograde and retrograde

872 history. The rate of this progressive strain localization is however unknown, and in general,

873 poorly known in similar geological contexts. Are all shear zones coeval, do they work at the

874 same time or can we see a sequential development until final localization on the brittle Vari

875 Detachment? As an open question left for further work, we can say that modeling the

876 evolution of the CBU accretionary complex and understanding the mechanical behavior of the

877 subduction interface requires quantifying the rate of strain localization. Acquisition of

878 detailed time constraints along the P-T path is fundamental in determining the role and the

879 importance of the shear zones bounding the subunits of Syros, it is a pre-requisite for further 880 considerations on exhumation mechanisms.

882 Acknowledgments

883 This work has received funding from the European Research Council (ERC) under the

884 seventh Framework Programme of the European Union (ERC Advanced Grant, grant 885 agreement No 290864, RHEOLITH) and from the Institut Universitaire de France. It is a 886 contribution of the Labex VOLTAIRE. We forward our warmest thanks to Catherine and 887 Jacques Arvanitis for their magnificent hospitality and friendship all through the years since 
reviewer for insightful suggestions.

\section{References}

Altherr, R., Kreuzer, H., Wendt, I., Lenz, H., Wagner, G.A., Keller, J., Harre, W., Hohndorf, A., 1982. A late Oligocene/early Miocene high temperature belt in the Attic-Cycladic crystalline complex (SE Pelagonian, Greece). Geologisches Jahrbuch E 23, 97-164.

Altherr, R., Schliestedt, M., Okrusch, M., Seidel, E., Kreuzer, H., Harre, W., Lenz, H., Wendt, I., Wagner, G.A., 1979. Geochronology of high-pressure rocks on Sifnos (Cyclades, Greece). Contributions to Mineralogy and Petrology 70, 245-255.

Altherr, R., Siebel, W., 2002. I-type plutonism in a continental back-arc setting: Miocene granitoids and monzonites from the central Aegean Sea, Greece. Contrib Mineral Petrol 143, 397-415. doi:10.1007/s00410-002-0352-y

Andersen, T.B., Osmundsen, P.T., Jolivet, L., 1994. Deep crustal fabrics and a model for the extensional collapse of the southwest Norwegian Caledonides. Journal of Structural Geology 16, 1191-1203.

Andriessen, P.A.M., Banga, G., Hebeda, E.H., 1987. Isotopic age study of pre-Alpine rocks in the basal units on Naxos, Sikinos and Ios, Greek Cyclades. Geologie en Mijnbouw 66, 3-14.

Andriessen, P.A.M., Boelrijk, N., Hebeda, E.H., Priem, H.N.A., Verdurnen, E.A., Verschure, R.H., 1979. Dating the events of metamorphism and granitic magmatism in the Alpine Orogen of Naxos (Cyclades, Greece). Contributions to Mineralogy and Petrology 69, 215-225.

Ashley, K.T., Caddick, M.J., Steele-MacInnis, M.J., Bodnar, R.J., Dragovic, B., 2014. Geothermobarometric history of subduction recorded by quartz inclusions in garnet. Geochemistry, Geophysics, Geosystems $15,350-360$.

Augier, R., Jolivet, L., Gadenne, L., Lahfid, A., Driussi, O., 2015. Exhumation kinematics of the Cycladic Blueschists unit and back-arc extension, insight from the Southern Cyclades (Sikinos and Folegandros Islands, Greece), Tectonics, 34, doi: 10.1002/2014TC003664. Received 24, 2.

Austrheim, H., Griffin, W. L., 1985. Shear deformation and eclogite formation within granulite-facies anorthosites of the Bergen Arcs, western Norway. Chemical Geology 50, 267-281.

Avigad, D., 1993. Tectonic juxtaposition of blueschists and greenschists in Sifnos Island (Aegean Sea) ; implications for the structure of the Cycladic blueschist belt. Journal of Structural Geology 15, 14591469.

Avigad, D., Garfunkel, Z., 1991. Uplift and exhumation of high-pressure metamorphic terrains: the example of the Cycladic blueschist belt (Aegean Sea). Tectonophysics 188, 357-372.

Beaudoin, A., Laurent, V., Augier, R., Rabillard, A., Jolivet, L., Arbaret, L., and Menant, A., 2015, The Ikaria Metamorphic Core Complex between the Cyclades and the Menderes massif: submitted.

Bell, T.H., Brothers, R.N., 1985. Development of P-T prograde and P-retrograde, T-prograde isogradic surfaces during blueschist to eclogite regional deformation/metamorphism in New Caledonia, as indicated by progressively developed porphyroblast microstructures. Journal of Metamorphic Geology 3, 59-78.

Blake, M.C., Bonneau, M., Geyssant, J., Kienast, J.R., Lepvrier, C., Maluski, H., Papanikolaou, D., 1981. A geological reconnaissance of the Cycladic blueschist belt, Greece. Geological Society of America Bulletin 92, 247-254.

Bolhar, R., Ring, U., Allen, C.M., 2010. An integrated zircon geochronological and geochemical investigation into the Miocene plutonic evolution of the Cyclades, Aegean Sea, Greece: Part 1: Geochronology. Contributions to Mineralogy and Petrology 160, 719-742.

Bonneau, M., 1984. Correlation of the Hellenide nappes in the south-east Aegean and their tectonic reconstruction. Geological Society, London, Special Publications 17, 517-527.

Bonneau, M., Blake, M.C., Gueyssant, J., Kienast, J.R., Lepvrier, C., Maluski, H., Papanikolaou, D., 1980a. Sur la signification des séries métamorphiques (schistes bleus) des cyclades (Héllènides, Grèce). L'exemple 

de l'île de Syros. CR Seances Acad. Sci. Ser. D 290, 1463-1466.

Bonneau, M., Kienast, J., Lepvrier, C., Maluski, H., 1980b. Tectonique et métamorphisme haute pression d'âge Eocène dans les Hellénides: exemple de l'île de Syros (Cyclades, Grèce). CR Acad. Sci., Paris 291, $171-174$.

Bonneau, M., Kienast, J.R., 1982. Subduction, collision et schistes bleus; l'exemple de l'Egee (Grece). Bulletin de la société Géologique de France 785-791.

Bröcker, M., Baldwin, S., Arkudas, R., 2013. The geological significance of 40Ar/39Ar and Rb-Sr white mica ages from Syros and Sifnos, Greece: a record of continuous (re) crystallization during exhumation? Journal of Metamorphic Geology 31, 629-646.

Bröcker, M., Enders, M., 2001. Unusual bulk-rock compositions in eclogite-facies rocks from Syros and Tinos (Cyclades, Greece): implications for U-Pb zircon geochronology. Chemical Geology 175, 581-603.

Bröcker, M., Franz, L., 1998. Rb-Sr isotope studies on Tinos Island (Cyclades, Greece): additional time constraints for metamorphism, extent of infiltration-controlled overprinting and deformational activity. Geological Magazine 135, 369-382.

Bröcker, M., Franz, L., 2006. Dating metamorphism and tectonic juxtaposition on Andros Island (Cyclades, Greece): results of a $\mathrm{Rb}-\mathrm{Sr}$ study. Geological Magazine 143, 609-620.

Bröcker, M., Kreuzer, H., Matthews, A., Okrusch, M., 1993. 40Ar/39Ar and oxygen isotope studies of polymetamorphism from Tinos Island, Cycladic blueschist belt, Greece. Journal of Metamorphic Geology 11, 223-240.

Bröcker, M., Enders, M., 1999. U-Pb zircon geochronology of unusual eclogite-facies rocks from Syros and Tinos (Cyclades, Greece). Geological Magazine 136, 111-118.

Brun, J.-P., Faccenna, C., 2008. Exhumation of high-pressure rocks driven by slab rollback. Earth and Planetary Science Letters 272, 1-7.

Brun, J.-P., Sokoutis, D., 2010. 45 my of Aegean crust and mantle flow driven by trench retreat. Geology 38 , 815-818.

Brunet, C., Monié, P., Jolivet, L., \& Cadet, J. P., 2000. Migration of compression and extension in the Tyrrhenian Sea, insights from $40 \mathrm{Ar} / 39 \mathrm{Ar}$ ages on micas along a transect from Corsica to Tuscany. Tectonophysics 321, 127-155.

Buick, I.S., 1991. The late Alpine evolution of an extensional shear zone, Naxos, Greece. Journal of the Geological Society 148, 93-103.

Burg, J. P., Proust, F., Tapponnier, P., Chen, G. M., 1983. Deformation phases and tectonic evolution of the Lhasa block (southern Tibet, China). Eclogae Geologicae Helvetiae 76, 643-665.

Denèle, Y., Lecomte, E., Jolivet, L., Lacombe, O., Labrousse, L., Huet, B., Le Pourhiet, L., 2011. Granite intrusion in a metamorphic core complex: the example of the Mykonos laccolith (Cyclades, Greece). Tectonophysics 501, 52-70.

Dercourt, J., Zonenshain, L.P., Ricou, L.-E., Kazmin, V.G., Le Pichon, X., Knipper, A.L., Grandjacquet, C., Sbortshikov, I.M., Geyssant, J., Lepvrier, C., others, 1986. Geological evolution of the Tethys belt from the Atlantic to the Pamirs since the Lias. Tectonophysics 123, 241-315.

Dragovic, B., Samanta, L.M., Baxter, E.F., Selverstone, J., 2012. Using garnet to constrain the duration and rate of water-releasing metamorphic reactions during subduction: An example from Sifnos, Greece. Chemical Geology 314, 9-22.

Duchene, S., Aissa, R., Vanderhaeghe, O., 2006. Pressure-temperature-time evolution of metamorphic rocks from Naxos (Cyclades, Greece): constraints from thermobarometry and $\mathrm{Rb} / \mathrm{Sr}$ dating. Geodinamica Acta 19, 301-321.

Dürr, S., Altherr, R., Keller, J., Okrusch, M., Seidel, E., 1978. The median Aegean crystalline belt: stratigraphy, structure, metamorphism, magmatism. Alps, Apennines, Hellenides 38, 455-476.

Epard, J. L., \& Steck, A., 2008. Structural development of the Tso Morari ultra-high pressure nappe of the Ladakh Himalaya. Tectonophysics 451, 242-264.

Evans, B. W., 1990. Phase relations of epidote-blueschists. Lithos 25, 3-23.

Faure, M., Bonneau, M., Pons, J., 1991. Ductile deformation and syntectonic granite emplacement during the late Miocene extension of the Aegea (Greece). Bulletin de la Societé géologique de France 5, 3-11.

Gautier, P., 1995. Géométrie crustale et cinématique de l'extension tardiorogénique dans le domaine centre égéen: Iles des Cyclades et D’eubée (Grèce). Mem. de Geosci. Rennes 61, 417 pp.

Grasemann, B., Petrakakis, K., 2007. Evolution of the Serifos metamorphic core complex. Inside the Aegean Core Complexes. Journal of the Virtual Explorer, Electronic Edition.

Grasemann, B., Schneider, D.A., Stöckli, D.F., Iglseder, C., 2012. Miocene bivergent crustal extension in the Aegean: Evidence from the western Cyclades (Greece). Lithosphere L164-1.

Groppo, C., Forster, M., Lister, G., Compagnoni, R., 2009. Glaucophane schists and associated rocks from Sifnos (Cyclades, Greece): New constraints on the P-T evolution from oxidized systems. Lithos 109, 254-273. 
Gupta, S., Bickle, M.J., 2004. Ductile shearing, hydrous fluid channelling and high-pressure metamorphism along the basement-cover contact on Sikinos, Cyclades, Greece. Geological Society, London, Special Publications 224, 161-175.

Hausmann, H., 1845. Beiträge zur Oryktographie von Syra. Journal für Praktische Chemie 34, 238-241.

Hecht, J., 1985, Geological map of Greece 1:50.000, Syros Island: Athens, Institute of Geology and Mineral Exploration, 1 sheet.

Huet, B., 2010. Rhéologie de la lithosphère continentale: L'exemple de la Mer Egée. PhD thesis, Université Pierre et Marie Curie-Paris VI, 402 pp.

Huet, B., Labrousse, L., Jolivet, L., 2009. Thrust or detachment? Exhumation processes in the Aegean: insight from a field study on Ios (Cyclades, Greece). Tectonics 28.

Huet, B., Le Pourhiet, L., Labrousse, L., Burov, E., Jolivet, L., 2011. Post-orogenic extension and metamorphic core complexes in a heterogeneous crust: the role of crustal layering inherited from collision. Application to the Cyclades (Aegean domain). Geophysical Journal International 184, 611-625.

Iglseder, C., Grasemann, B., Schneider, D.A., Petrakakis, K., Miller, C., Klötzli, U.S., Thöni, M., Zámolyi, A., Rambousek, C., 2009. I and S-type plutonism on Serifos (W-Cyclades, Greece). Tectonophysics 473, 69-83.

Jansen, J.B.H., 1973. Geological map of Naxos (1/50 000). Nation. Inst. Geol. Mining Res., Athens.

Jolivet, L., Brun, J.-P., 2010. Cenozoic geodynamic evolution of the Aegean. International Journal of Earth Sciences 99, 109-138.

Jolivet, L., Faccenna, C., 2000. Mediterranean extension and the Africa-Eurasia collision. Tectonics 19, 10951106.

Jolivet, L., Faccenna, C., Goffé, B., Burov, E., Agard, P., 2003. Subduction tectonics and exhumation of highpressure metamorphic rocks in the Mediterranean orogens. American Journal of Science 303, 353-409.

Jolivet, L., Lecomte, E., Huet, B., Denèle, Y., Lacombe, O., Labrousse, L., Le Pourhiet, L., Mehl, C., 2010. The north cycladic detachment system. Earth and Planetary Science Letters 289, 87-104.

Jolivet, L., Menant, A., Sternai, P., Rabillard, A., Arbaret, L., Augier, R., Laurent, V., Beaudoin, A., Grasemann, B., Huet, B., Labrousse, L., Le Pourhiet, L., 2015. The geological signature of a slab tear below the Aegean. Tectonophysics.

Jolivet, L., Rimmelé, G., Oberhänsli, R., Goffé, B., Candan, O., 2004. Correlation of syn-orogenic tectonic and metamorphic events in the Cyclades, the Lycian nappes and the Menderes massif. Geodynamic implications. Bulletin de la Société Géologique de France 175, 217-238.

Keay, S., 1998. The geological evolution of the Cyclades, Greece: constraints from SHRIMP U-Pb geochronology. Australian National University.

Keay, S., Lister, G., Buick, I., 2001. The timing of partial melting, Barrovian metamorphism and granite intrusion in the Naxos metamorphic core complex, Cyclades, Aegean Sea, Greece. Tectonophysics 342, 275-312.

Keiter, M., Ballhaus, C., Tomaschek, F., 2011. A new geological map of the Island of Syros (Aegean Sea, Greece): Implications for lithostratigraphy and structural history of the Cycladic Blueschist Unit. Geological Society of America Special Papers 481, 1-43.

Keiter, M., Piepjohn, K., Ballhaus, C., Lagos, M., Bode, M., 2004. Structural development of high-pressure metamorphic rocks on Syros island (Cyclades, Greece). Journal of Structural Geology 26, 1433-1445.

Kuhlemann, J., Frisch, W., Dunkl, I., Kázmér, M., Schmiedl, G., 2004. Miocene siliciclastic deposits of Naxos Island: Geodynamic and environmental implications for the evolution of the southern Aegean Sea (Greece). Geological Society of America Special Papers 378, 51-65.

Labrousse, L., Jolivet, L., Andersen, T.B., Agard, P., Hébert, R., Maluski, H., Schärer, U., 2004. Pressuretemperature-time deformation history of the exhumation of ultra-high pressure rocks in the Western Gneiss Region, Norway. Geological Society of America Special Papers 380, 155-183.

Lagos, M., Scherer, E.E., Tomaschek, F., Münker, C., Keiter, M., Berndt, J., Ballhaus, C., 2007. High precision Lu-Hf geochronology of Eocene eclogite-facies rocks from Syros, Cyclades, Greece. Chemical Geology 243, 16-35.

Laurent, V., Beaudoin, A., Jolivet, L., Arbaret, L., Augier, R., and Rabillard, A., 2015. Interactions between extensional shear zones and syn-tectonic granite intrusion: the example of Ikaria island (Cyclades, Greece): submitted.

Lecomte, E., Jolivet, L., Lacombe, O., Denèle, Y., Labrousse, L., Le Pourhiet, L., 2010. Geometry and kinematics of a low-angle normal fault on Mykonos island (Cyclades, Greece): Evidence for slip at shallow dip. Tectonics 29.

Lee, J., Lister, G.S., 1992. Late Miocene ductile extension and detachment faulting, Mykonos, Greece. Geology $20,121-124$.

Liou, J. G., Tsujimori, T., Zhang, R. Y., Katayama, I., \& Maruyama, S., 2004. Global UHP metamorphism and continental subduction/collision: the Himalayan model. International Geology Review 46, 1-27. 
Maluski, H., Bonneau, M., Kienast, J.R., 1987. Dating the metamorphic events in the Cycladic area; $39 \mathrm{Ar} / 40 \mathrm{Ar}$ data from metamorphic rocks of the Island of Syros (Greece). Bulletin de la Société géologique de France 3, 833-842.

Matthews, A., Schliestedt, M., 1984. Evolution of the blueschist and greenschist-facies rocks of Sifnos, Cyclades, Greece. Contr. Mineral. and Petrol. 88, 150-163. doi:10.1007/BF00371419

Menant, A., Jolivet, L., Augier, R., Skarpelis, N., 2013. The North Cycladic Detachment System and associated mineralization, Mykonos, Greece: Insights on the evolution of the Aegean domain. Tectonics 32, 433452.

Menant, A., Jolivet, L., Vrielynck, B., 2015. From crust to mantle dynamics, insight from kinematic reconstructions and magmatic evolution of the eastern Mediterranean region since the late Cretaceous, Tectonophysics.

Okrusch, M., Bröcker, M., 1990. Eclogites associated with high-grade blueschists in the Cyclades archipelago, Greece: a review. European Journal of Mineralogy 451-478.

Parra, T., Vidal, O., Jolivet, L., 2002. Relation between the intensity of deformation and retrogression in blueschist metapelites of Tinos Island (Greece) evidenced by chlorite-mica local equilibria. Lithos 63, 41-66.

Patzak, M., Okrusch, M., Kreuzer, H., 1994. The Akrotiri Unit on the island of Tinos, Cyclades, Greece: Witness to a lost terrane of Late Cretaceous age.(With 18 figures and 8 tables in the text). Neues Jahrbuch fur Geologie und Palaontologie-Abhandlungen 194, 211-252.

Pe-Piper, G., Piper, D.J., Matarangas, D., 2002. Regional implications of geochemistry and style of emplacement of Miocene I-type diorite and granite, Delos, Cyclades, Greece. Lithos 60, 47-66.

Peacock, S.M., 1993. The importance of blueschist-eclogite dehydration reactions in subducting oceanic crust. Geological Society of America Bulletin 105, 684-694.

Philippon, M., Brun, J.-P., Gueydan, F., 2011. Tectonics of the Syros blueschists (Cyclades, Greece): From subduction to Aegean extension. Tectonics 30.

Photiades, A., Keay, S., 2003. Geological and geochronological data for Sikinos and Folegandros metamorphic units (Cyclades, Greece): Their tectono-stratigraphic significance.

Putlitz, B., Cosca, M.A., Schumacher, J.C., 2005. Prograde mica 40 Ar/39 Ar growth ages recorded in high pressure rocks (Syros, Cyclades, Greece). Chemical Geology 214, 79-98.

Rabillard, A., Arbaret, L., Jolivet, L., Le Breton, N., Gumiaux, C., Augier, R., Grasemann, B., 2015. Interactions between plutonism and detachments during Metamorphic Core Complex formation, Serifos Island (Cyclades, Greece). Tectonics. DOI: 10.1002/2014TC003650.

Raimbourg, H., Jolivet, L., Labrousse, L., Leroy, Y., Avigad, D., 2005. Kinematics of syn-eclogite deformation in the Bergen Arcs, Norway, implications for exhumation mechanisms. Special Publication-Geological Society of London 243, 175-192.

Ring, U., Glodny, J., Will, T., Thomson, S., 2010. The Hellenic subduction system: high-pressure metamorphism, exhumation, normal faulting, and large-scale extension. Annual Review of Earth and Planetary Sciences $38,45-76$.

Ring, U., Thomson, S.N., Bröcker, M., 2003. Fast extension but little exhumation: the Vari detachment in the Cyclades, Greece. Geological Magazine 140, 245-252.

Roche, V., Laurent, V., Cardello, G. L., Jolivet, L., Scaillet, S., submitted. The anatomy of the Cycladic Blueschist Unit on Sifnos Island (Cyclades, Greece), Journal of Geodynamics.

Rosenbaum, G., Avigad, D., Sánchez-Gómez, M., 2002. Coaxial flattening at deep levels of orogenic belts: evidence from blueschists and eclogites on Syros and Sifnos (Cyclades, Greece). Journal of Structural Geology 24, 1451-1462.

Sanchez-Gomez, M., Avigad, D., Heimann, A., 2002. Geochronology of clasts in allochthonous Miocene sedimentary sequences on Mykonos and Paros islands: implications for back-arc extension in the Aegean Sea. Journal of the Geological Society 159, 45-60.

Schliestedt, M., Altherr, R., Matthews, A., 1987. Evolution of the Cycladic crystalline complex: petrology, isotope geochemistry and geochronolgy, in: Chemical Transport in Metasomatic Processes. Springer, pp. 389-428.

Schliestedt, M., Matthews, A., 1987. Transformation of blueschist to greenschist-facies rocks as a consequence of fluid infiltration, Sifnos (Cyclades), Greece. Contributions to Mineralogy and Petrology 97, 237-250.

Schmädicke, E., Will, T.M., 2003. Pressure-temperature evolution of blueschist-facies rocks from Sifnos, Greece, and implications for the exhumation of high-pressure rocks in the Central Aegean. Journal of Metamorphic Geology 21, 799-811.

Schumacher, J.C., Brady, J.B., Cheney, J.T., Tonnsen, R.R., 2008. Glaucophane-bearing marbles on Syros, Greece. Journal of Petrology 49, 1667-1686.

Soukis, K., Stöckli, D.F., 2013. Structural and thermochronometric evidence for multi-stage exhumation of southern Syros, Cycladic islands, Greece. Tectonophysics 595, 148-164. 
1119

1120

1121

1122

1123

1124

1125

1126

1127

1128

1129

1130

1131

1132

1133

1134

1135

1136

1137

1138

1139

1140

1141

1142

1143

1144

Stouraiti, C., Mitropoulos, P., Tarney, J., Barreiro, B., McGrath, A.M., Baltatzis, E., 2010. Geochemistry and petrogenesis of late Miocene granitoids, Cyclades, southern Aegean: Nature of source components. Lithos 114, 337-352.

Terry, M. P., Heidelbach, F., 2006. Deformation-enhanced metamorphic reactions and the rheology of highpressure shear zones, Western Gneiss Region, Norway. Journal of Metamorphic Geology 24, 3-18.

Tomaschek, F., Kennedy, A.K., Villa, I.M., Lagos, M., Ballhaus, C., 2003. Zircons from Syros, Cyclades, Greece-recrystallization and mobilization of zircon during high-pressure metamorphism. Journal of Petrology 44, 1977-2002.

Trotet, F., Jolivet, L., Vidal, O., 2001a. Tectono-metamorphic evolution of Syros and Sifnos islands (Cyclades, Greece). Tectonophysics 338, 179-206.

Trotet, F., Vidal, O., Jolivet, L., 2001b. Exhumation of Syros and Sifnos metamorphic rocks (Cyclades, Greece). New constraints on the PT paths. European Journal of Mineralogy 13, 901-902.

Van Hinsbergen, D.J.J., Zachariasse, W.J., Wortel, M.J.R., Meulenkamp, J.E., 2005. Underthrusting and exhumation: a comparison between the External Hellenides and the "hot" Cycladic and "cold" South Aegean core complexes (Greece). Tectonics 24.

Vanderhaeghe, O., 2004. Structural development of the Naxos migmatite dome. Geological Society of America Special Papers 380, 211-227.

Vitale-Brovarone, A., Groppo, C., Hetenyi, G., Compagnoni, R., Malavieille, J., 2011. Coexistence of lawsonitebearing eclogite and blueschist: phase equilibria modelling of Alpine Corsica metabasalts and petrological evolution of subducting slabs. Journal of Metamorphic Geology 29, 583-600.

Wijbrans, J.R., McDougall, I., 1986. 40Ar/39Ar dating of white micas from an Alpine high-pressure metamorphic belt on Naxos (Greece): the resetting of the argon isotopic system. Contributions to Mineralogy and Petrology 93, 187-194.

Wijbrans, J.R., Schliestedt, M., York, D., 1990. Single grain argon laser probe dating of phengites from the blueschist to greenschist transition on Sifnos (Cyclades, Greece). Contributions to Mineralogy and Petrology 104, 582-593. 